\title{
The 860-Ma, Cordilleran-Type Guandaoshan Dioritic Pluton in the Yangtze Block, SW China: Implications for the Origin of Neoproterozoic Magmatism
}

\author{
Wei-Hua Sun and Mei-Fu Zhou \\ Department of Earth Sciences, University of Hong Kong, Hong Kong, China \\ (e-mail: weihua@hkusua.hku.hk)
}

\begin{abstract}
A B S T R A C T
The tectonic setting of the widespread Neoproterozoic igneous rocks in South China has long been a matter of debate. Situated in the western margin of the Yangtze Block of South China, the Guandaoshan pluton is composed of diorite in the core and quartz diorite in the margin. Both types contain abundant mafic enclaves and mafic dikes. This pluton is dated at $858 \pm 7 \mathrm{Ma}$ by the SHRIMP zircon U-Pb method. The rocks have $\mathrm{SiO}_{2}$ contents of 52.8-63.8 wt $\%, \mathrm{Al}_{2} \mathrm{O}_{3}$ contents of 17.4-20.6 wt\%, $\mathrm{Na}_{2} \mathrm{O}$ contents of $2.14-3.74 \mathrm{wt} \%$, and $\mathrm{K}_{2} \mathrm{O}$ contents of $0.44-1.61 \mathrm{wt} \%$. They are calcalkaline with an $\mathrm{Al}$ saturation index, $\mathrm{A} / \mathrm{CNK}<1\left(\right.$ molar $\left.\mathrm{Al}_{2} \mathrm{O}_{3} /\left[\mathrm{CaO}+\mathrm{Na}_{2} \mathrm{O}+\mathrm{K}_{2} \mathrm{O}\right]\right)$ and $\mathrm{A} / \mathrm{NK}>1$, and they have Fe numbers $<0.8\left(\mathrm{Fe}_{2} \mathrm{O}_{3} /\left[\mathrm{Fe}_{2} \mathrm{O}_{3}+\mathrm{MgO}\right]\right)$. Their total rare earth element (REE) contents range from 19 to $45 \mathrm{ppm}$, with concave chondrite-normalized patterns slightly depleted in middle REEs, indicating extensive amphibole fractionation. Their whole-rock $\varepsilon_{\mathrm{Nd}}(t)$ values range from +3.9 to +5.1 , and initial ${ }^{87} \mathrm{Sr} /{ }^{86} \mathrm{Sr}$ ratios range from 0.7028 to 0.7033 . They have zircon $\varepsilon_{\mathrm{Hf}}(t)$ values ranging from +11 to +17 , with mean Hf model ages of around $860 \mathrm{Ma}$, clearly indicating a depleted-mantle source. In the primitive mantle-normalized trace element spider diagram, the rocks show pronounced enrichment of $\mathrm{Rb}, \mathrm{Ba}, \mathrm{Th}$, and $\mathrm{Pb}$ and depletion of $\mathrm{Nb}, \mathrm{Ta}$, and $\mathrm{Ti}$, a typical arc signature. The Guandaoshan pluton is an amphibole-rich, calc-alkaline, Cordilleran-type granitoid, a typical product of subductionzone magmatism. The occurrence of this Neoproterozoic Cordilleran-type granitoid suggests that the western margin of the Yangtze Block was an Andean-type continental margin at that time, rather than mantle plume-related rifting setting.
\end{abstract}

Online enhancements: appendix tables, color version of figure 2.

\section{Introduction}

Neoproterozoic igneous rocks crop out extensively along the margins of the Yangtze Block, South China (fig. 1a). There are two conflicting models describing their petrogenesis and tectonic significance; the dispute is centered on the source of heat required to produce these voluminous igneous rocks and their possible links to the reconstruction of Rodinia (Li et al. 1995, 1999, 2002, 2003a, 2003b, 2003c; Zhou et al. 2002a, 2002b, 2006a, 2006b). One group holds that the Neoproterozoic magmatic activity, which occurred during the interval between 860 and $740 \mathrm{Ma}$, was mantle plume related and further infers that the South China Block was located in a central part of Rodinia before breakup

Manuscript received November 16, 2007; accepted February 25, 2008. by a mantle superplume (Li et al. 1995, 1999, 2003a, $2003 b, 2003 c, 2006)$. In contrast, the other school envisages that this Neoproterozoic magmatism was related to major continental arcs along the margins of the Yangtze Block (Guo et al. 1996; Zhou et al. 2002a, 2002b, 2006a, 2006b; Wang et al. 2004), indicating that the Yangtze Block was an isolated microplate or that it flanked some part of Rodinia (Zhou et al. 2002b, 2006a).

The Neoproterozoic igneous rocks in South China are chiefly felsic and mafic in character, leading some workers to suggest that they represent a rift-related bimodal assemblage ( $\mathrm{Li}$ et al. 2002, 2003c). However, intermediate rocks are present, although they have rarely been reported. Likewise, the petrogenesis and significance of these rocks are not known. 


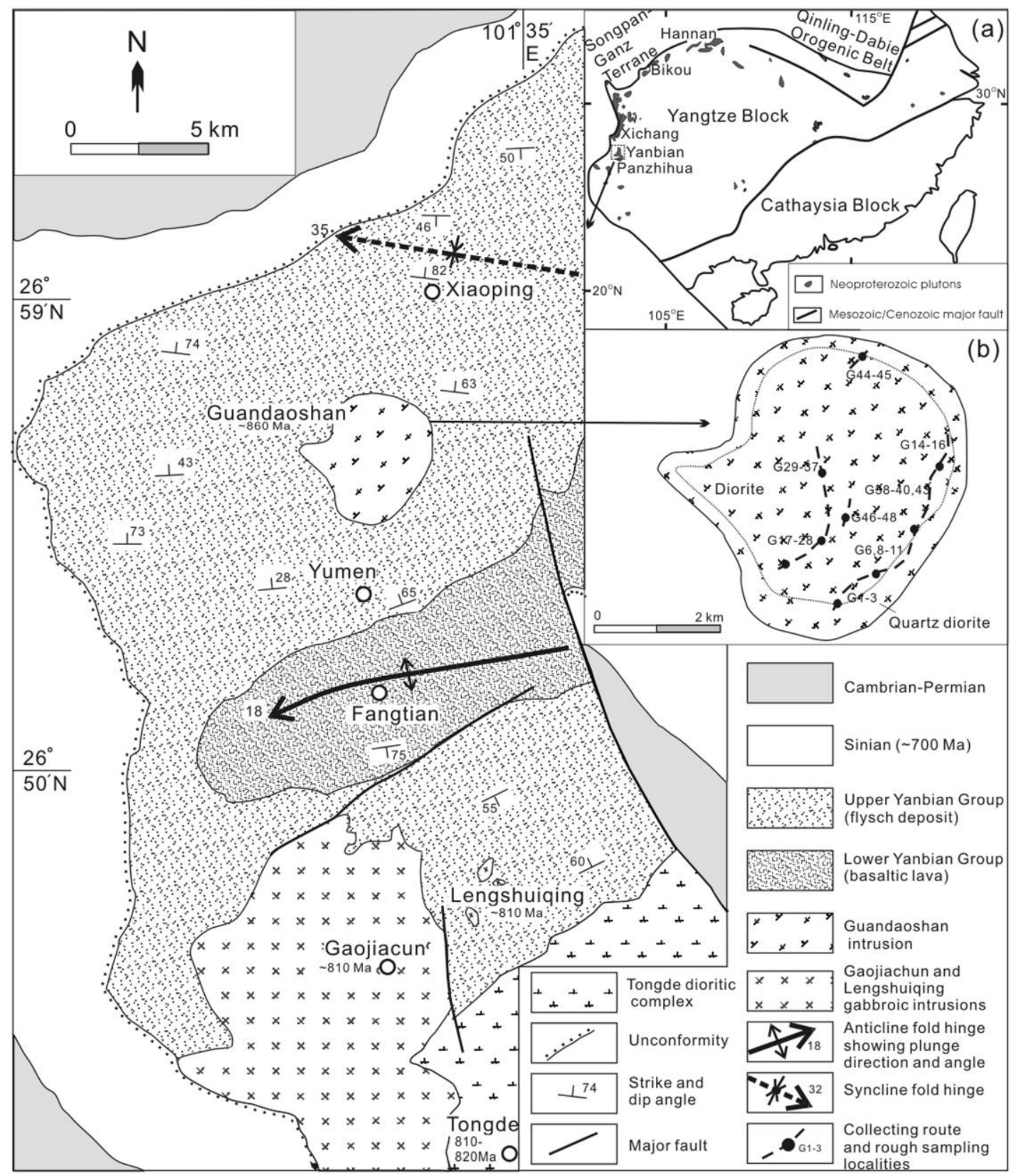

Figure 1. Simplified geological map of the Yanbian Terrane (after BGMRSP 1972). $a$, Tectonic units of South China and the general distribution of Neoproterozoic plutons along the western margin of the Yangtze Block; $b$, the two major phases of the Guandaoshan pluton and rough sampling locations.

Located in the western margin of the Yangtze Block, the $~ 860-M a$ Guandaoshan dioritic pluton occurs in the Yanbian region, southern Sichuan Province (fig. 1). Although Li et al. (2003b) showed that this pluton had a clear arc signature, they interpreted it as being crustal derived and its arc affinities inherited from a preexisting igneous protolith. They suggested that the pluton represents the earliest product of a mantle plume that initiated the breakup of Rodinia (Li et al. 2003b). Here we present detailed geochronological, geochemical, and whole-rock Sr-Nd and zircon Lu-Hf isotopic data for the Guandaoshan pluton in order to provide new constraints on its origin. This article documents that this pluton, having a mantle-derived origin, is a typical Cordilleran-type granitoid pro- 
duced by oceanic-plate subduction at a continental margin, and thus it sheds light on the nature of the abundant Neoproterozoic igneous assemblages in South China.

\section{Geological Setting}

Regional Geology. South China consists of the Yangtze Block in the northwest and the Cathaysia Block in the southeast (fig. 1). The Yangtze Block is separated from the North China Block by the Qinling-Dabie orogenic belt and bounded to the west by the Songpan-Ganz Terrane of the Tibetan Plateau. The Songpan-Ganz Terrane is a prominent triangular basin filled with Triassic deep-marine flysch deposits (Zhou and Graham 1996). The Yangtze Block comprises metamorphic basement complexes and Neoproterozoic to Cenozoic cover rocks (Yan et al. 2003). The former includes gneiss, mica schist, amphibolite, marble, and quartzite, and the latter consists mainly of carbonate, clastic, and volcanic rocks (SBGMR 1991).

The western margin of the Yangtze Block is marked by the $1000-\mathrm{km}$-long Hannan-Panxi belt ("Panxi" denotes the Panzhihua-Xichang region; fig. 1a), a major continental arc, within which the igneous rocks have ages commonly ranging from 860 to $740 \mathrm{Ma}$ (Zhou et al. 2002a, 2002b, 2006a, 2006b; Zhao and Zhou 2007a, 2007b). Within this belt there are several arc assemblages including, from north to south, the Hannan (Zhou et al. 2002a), Bikou (Yan et al. 2004; Druschke et al. 2006; Xiao et al. 2007), and Yanbian terranes (Zhou et al. 2006a; Sun et al. 2007; fig. 1a).

The Yanbian Terrane. The Yanbian Terrane, including the Yanbian Group and several associated intrusions (fig. 1), has been described by many authors (Zhou et al. 2006a; Li et al. 2006; Sun et al. 2007). The Yanbian Group is a $>6-\mathrm{km}$-thick, volcanic-sedimentary sequence composed of basaltic lavas in the lower part and flysch deposits in the upper part. It has been recently interpreted as a back-arc basin sequence (Du et al. 2005; Li et al. 2006; Sun et al. 2007). The exact age of this unfossiliferous group remains controversial, although it has a well-constrained Neoproterozoic age, based on zircon dating of the lavas and sandstones (Du et al. 2005; Zhou et al. 2006a; Li et al. 2006). The rocks of the Yanbian Group generally underwent only very low-grade greenschist facies metamorphism (BGMRSP 1972). Well-preserved bedding generally strikes roughly E-W and dips $50^{\circ}-70^{\circ}$ to the north. Major folds include the Fangtian anticline in the south and the Xiaoping syncline in the north (fig. 1). The Sinian strata, comprising glacial deposits, volcanic rocks, siliciclastic rocks, and carbonates, rest unconformably on the Yanbian Group and are overlain by the younger Paleozoic and Mesozoic successions (BGMRSP 1972; fig. 1).

In the Yanbian Terrane, the Yanbian Group is intruded by the Guandaoshan and Tongde dioritic plutons and the Gaojiacun and Lengshuiqing gabbroic plutons (fig. 1). The Gaojiacun and Lengshuiqing plutons have SHRIMP zircon $\mathrm{U}-\mathrm{Pb}$ ages of $806 \pm 4$ and $811 \pm 3 \mathrm{Ma}$, respectively (Zhou et al. 2006a). The former is compositionally zoned from wehrlite in the core, through olivine gabbro and gabbro, to diorite in the margin, whereas the latter is a much smaller mafic-ultramafic intrusion containing minable Ni-Cu-PGE sulfide deposits (Zhou et al. 2006a). The Tongde pluton consists of quartz diorite-tonalite and minor gabbro and has been dated at $813 \pm 14$ and $820 \pm 13 \mathrm{Ma}$ (Li et al. $2003 c$ and reference therein). These approximately contemporaneous plutons ( 810-820 Ma), together with the Yanbian Group, have been interpreted as one of the typical Neoproterozoic arc assemblages in the western margin of the Yangtze Block (Zhou et al. 2006a; Sun et al. 2007) and as products of a mantle superplume (Li et al. 2003b, 2006).

\section{Field Relations and Petrography}

The Guandaoshan pluton, exposed over an area of approximately $20 \mathrm{~km}^{2}$, is composed mostly of diorite in the center and quartz diorite in the margin (fig. 1b; BGMRSP 1972). It is hosted in the upper part of the Yanbian Group, and the boundaries are marked by chilled margins and contact metamorphism. Near the boundaries there are hornfels of the country rocks (fig. $2 a$ ). Smaller splays protruding from the main intrusive body are also found intruding the country rocks (fig. $2 b$ ).

Within the diorite, there are locally coarsegrained amphibole cumulates with crystals generally $2-3 \mathrm{~cm}$ across but ranging up to $6 \mathrm{~cm}$ in length (fig. 2c). Mafic enclaves are abundant in the quartz diorite, and most of them have sharp, well-defined contacts with the host rock (fig. 2d). Mafic dikes are widespread throughout this pluton (fig. 2e). In general, they strike N-S and dip steeply, although some are nearly horizontal.

The quartz diorites consist of plagioclase (45-55 modal\%), K-feldspar (5-10 modal\%), amphibole (10-25 modal\%), quartz (5-20 modal\%), and magnetite (2-5 modal\%), whereas the diorites contain plagioclase (50-65 modal\%), amphibole (25-40 modal\%), biotite (2-5 modal\%), magnetite (2-4 mo- 

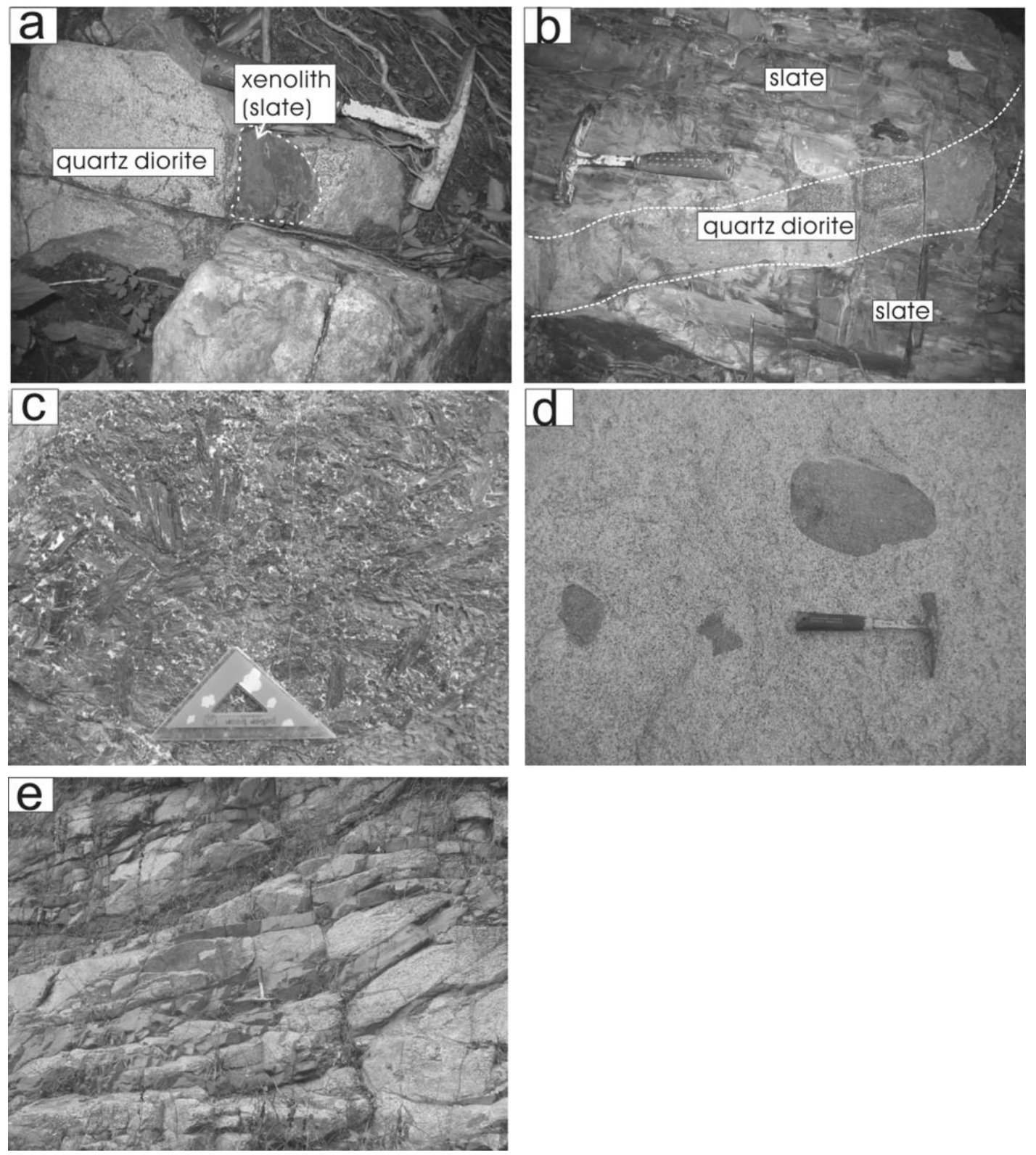

Figure 2. Field photos. $a$, Sedimentary xenolith enclosed in the quartz diorite of the Guandaoshan pluton; $b$, minor splay of the main Guandaoshan pluton clearly intruding carbonaceous slate of the Yanbian Group; $c$, locally observed amphibole cumulates; $d$, mafic enclaves in the Guandaoshan rocks; $e$, mafic dikes in the Guandaoshan pluton. A color version of this figure is available in the online edition or from the Journal of Geology office.

dal\%), and quartz (<5 modal\%). Minor clinopyroxene is also present in some samples. A few tonalite and granodiorite samples contain a little more quartz $\pm \mathrm{K}$-feldspar than the quartz diorite. Plagioclase commonly appears cloudy because of alteration to clay minerals, but some crystals still exhibit oscillatory zoning. Amphibole typically occurs as large, euhedral crystals up to $1 \mathrm{~cm}$ across. Minor accessory minerals include zircon, sphene, and apatite.

\section{Analytical Methods}

SHRIMP Zircon U-Pb Age Analyses. Zircon crystals were separated by a combination of heavyliquid and magnetic techniques and were hand- 
Table 1. SHRIMP U-Pb Isotopic Data for Zircons from Sample G25 of the Guandaoshan Pluton, Sichuan Province, SW China

\begin{tabular}{|c|c|c|c|c|c|c|c|c|c|c|}
\hline \multirow[b]{2}{*}{ Spot } & \multirow{2}{*}{$\begin{array}{c}{ }^{206} \mathrm{~Pb}_{\mathrm{c}} \\
(\%)\end{array}$} & \multirow{2}{*}{$\begin{array}{c}\mathrm{U} \\
(\mathrm{ppm})\end{array}$} & \multirow{2}{*}{$\begin{array}{c}\text { Th } \\
(\mathrm{ppm})\end{array}$} & \multirow[b]{2}{*}{$\mathrm{Th} / \mathrm{U}$} & \multirow{2}{*}{$\begin{array}{l}{ }^{206} \mathrm{~Pb}^{*} \\
(\mathrm{ppm})\end{array}$} & \multicolumn{3}{|c|}{ Isotopic ratio $( \pm \%)$} & \multicolumn{2}{|c|}{ Age (Ma) } \\
\hline & & & & & & ${ }^{207} \mathrm{~Pb}^{*} /{ }^{206} \mathrm{~Pb}^{*}$ & ${ }^{207} \mathrm{~Pb}^{*} /{ }^{235} \mathrm{U}$ & ${ }^{206} \mathrm{~Pb}^{*} /{ }^{238} \mathrm{U}$ & ${ }^{206} \mathrm{~Pb} /{ }^{238} \mathrm{U}$ & ${ }^{207} \mathrm{~Pb} /{ }^{206} \mathrm{~Pb}$ \\
\hline 1 & .46 & 149 & 152 & 1.06 & 18.0 & $.0681 \pm 1.8$ & $1.320 \pm 2.3$ & $.1405 \pm 1.4$ & $847 \pm 11$ & $873 \pm 38$ \\
\hline 2 & .51 & 148 & 155 & 1.08 & 18.1 & $.0678 \pm 1.8$ & $1.328 \pm 2.3$ & $.1421 \pm 1.4$ & $856 \pm 12$ & $862 \pm 38$ \\
\hline 3 & .61 & 114 & 87 & .79 & 14.1 & $.0673 \pm 2.4$ & $1.330 \pm 2.8$ & $.1433 \pm 1.5$ & $863 \pm 12$ & $847 \pm 50$ \\
\hline 4 & 1.22 & 84 & 51 & .63 & 10.3 & $.0671 \pm 4.0$ & $1.310 \pm 4.3$ & $.1416 \pm 1.6$ & $854 \pm 13$ & $841 \pm 83$ \\
\hline 5 & .62 & 132 & 129 & 1.01 & 16.2 & $.0684 \pm 2.4$ & $1.330 \pm 2.8$ & $.1411 \pm 1.5$ & $851 \pm 12$ & $879 \pm 50$ \\
\hline 6 & .94 & 78 & 42 & .56 & 9.59 & $.0684 \pm 3.6$ & $1.341 \pm 4.0$ & $.1422 \pm 1.6$ & $857 \pm 13$ & $880 \pm 75$ \\
\hline 7 & 1.07 & 108 & 87 & .83 & 13.5 & $.0697 \pm 4.0$ & $1.385 \pm 4.3$ & $.1441 \pm 1.5$ & $868 \pm 12$ & $920 \pm 82$ \\
\hline 8 & .55 & 149 & 167 & 1.16 & 18.2 & $.0665 \pm 2.1$ & $1.295 \pm 2.6$ & $.1411 \pm 1.5$ & $851 \pm 12$ & $823 \pm 43$ \\
\hline 9 & .38 & 140 & 126 & .93 & 17.4 & $.0684 \pm 1.9$ & $1.360 \pm 2.4$ & $.1442 \pm 1.5$ & $869 \pm 12$ & $880 \pm 39$ \\
\hline 10 & .50 & 113 & 84 & .76 & 14.1 & $.0654 \pm 3.1$ & $1.305 \pm 3.4$ & $.1446 \pm 1.5$ & $871 \pm 12$ & $788 \pm 65$ \\
\hline 11 & .43 & 139 & 111 & .82 & 17.0 & $.0663 \pm 2.1$ & $1.297 \pm 2.5$ & $.1418 \pm 1.5$ & $855 \pm 12$ & $817 \pm 43$ \\
\hline 12 & .69 & 139 & 110 & .82 & 17.1 & $.0668 \pm 2.4$ & $1.311 \pm 2.8$ & $.1424 \pm 1.5$ & $858 \pm 12$ & $830 \pm 51$ \\
\hline
\end{tabular}

Note. Errors are $1 \sigma ; \mathrm{Pb}_{\mathrm{c}}$ and $\mathrm{Pb}^{*}$ indicate the common and radiogenic portions, respectively. Common Pb corrected using measured ${ }^{204} \mathrm{~Pb}$.

picked and loaded in an epoxy resin mount. The mount was polished to effectively section the zircons in half and was then coated with gold. The U$\mathrm{Pb}$ isotopic analyses were performed using the SHRIMP-II at the Chinese Academy of Geological Sciences (Beijing), following standard procedures described by Song et al. (2002) and Jian et al. (2003). Interelement fractionation was corrected relative to the Research School of Earth Sciences, Australian National University-Geoscience Australia reference TEMORA (417 Ma). Data processing was carried out using the Isoplot program of Ludwig (1999). The uncertainties in ages are cited as $1 \sigma$, and the weighted mean ages are quoted at the $95 \%$ confidence level $(2 \sigma)$.

Major- and Trace-Element Analyses. Oxides of major elements were determined using $\mathrm{X}$-ray fluorescence (XRF) on fused glass beads at the University of Hong Kong. Trace elements, including rare earth elements (REEs), were analyzed on a VG PQ Excell inductively coupled plasma mass spectrometer (ICP-MS), also at the University of Hong Kong. The samples were digested with a mixture of HF and $\mathrm{HNO}_{3}$ in closed beakers in high-pressure bombs heated at $190^{\circ} \mathrm{C}$ for $2 \mathrm{~d}$ to ensure complete digestion (Qi et al. 2000). We used pure elemental standards for external calibration and BHVO-1 (basalt) and SY-4 (syenite) as reference materials. Accuracies of the XRF analyses are estimated to be better than $1 \%$ for $\mathrm{SiO}_{2}, 2 \%$ for other major oxides present in concentrations greater than $0.5 \mathrm{wt} \%$, and $5 \%$ for trace elements. The ICP-MS analyses have accuracies better than $5 \%$.

$\boldsymbol{R} \boldsymbol{b}$-Sr and Sm-Nd Isotope Analyses. $\mathrm{Rb}-\mathrm{Sr}$ and Sm$\mathrm{Nd}$ isotopic analyses were performed on a VG-354 thermal ionization magnetic sector mass spectrometer at the Institute of Geology and Geophysics,
Chinese Academy of Science, Beijing, following standard procedures described by Zhang et al. (2001). Mass fractionation corrections for Sr and Nd isotopic ratios were based on values of ${ }^{86} \mathrm{Sr} /{ }^{88} \mathrm{Sr}=$ 0.1194 and ${ }^{146} \mathrm{Nd} /{ }^{144} \mathrm{Nd}=0.7219$. Uncertainties in $\mathrm{Rb} / \mathrm{Sr}$ and $\mathrm{Sm} / \mathrm{Nd}$ ratios are less than $\pm 2 \%$ and $\pm 0.5 \%$ (relative), respectively.

Zircon Lu-Hf Isotopic Analyses. Lu-Hf isotopic analyses were carried out using a Thermo-Finnigan Neptune Multi-Collector ICP-MS coupled with a 193-nm ArF Excimer laser ablation system at the State Key Laboratory of Lithospheric Evolution in the Institute of Geology and Geophysics, Chinese Academy of Science, Beijing. The analytical procedures were described in detail by Wu et al. (2006). Interferences of ${ }^{176} \mathrm{Lu}$ and ${ }^{176} \mathrm{Yb}$ on ${ }^{176} \mathrm{Hf}$ and instrumental mass bias were corrected. We have adopted a decay constant of $1.867 \times 10^{-11} \mathrm{yr}^{-1}$ for ${ }^{176} \mathrm{Lu}$ (Söderlund et al. 2004) and the chondritic ratios of 0.282772 for ${ }^{176} \mathrm{Hf} /{ }^{177} \mathrm{Hf}$ and 0.0332 for ${ }^{176} \mathrm{Lu} /{ }^{177} \mathrm{Hf}$, as recommended by Blichert-Toft and Albarede (1997), to calculate $\varepsilon \mathrm{Hf}_{\mathrm{i}}$ values. One-stage model ages $\left(T_{\mathrm{DM}}\right)$ are calculated relative to a model depleted mantle with a present-day ${ }^{176} \mathrm{Hf} /{ }^{177} \mathrm{Hf}$ of 0.28325 and ${ }^{176} \mathrm{Lu} /$ ${ }^{177} \mathrm{Hf}$ of 0.0384 (Vervoort and Blichert-Toft 1999).

\section{Analytical Results}

SHRIMP Zircon U-Pb Dating. Zircons separated from a diorite sample, G25, collected from the central part of the Guandaoshan pluton $\left(26^{\circ} 55^{\prime} 52^{\prime \prime} \mathrm{N}\right.$, $101^{\circ} 30^{\prime} 05^{\prime \prime} \mathrm{E}$ ) are generally clear and euhedral and have oscillatory or linear zoning in cathodoluminescence $(C L)$ images, suggesting an igneous origin. The SHRIMP zircon U-Pb analytical data are shown in table 1. Twelve analyses of individual zircon grains constitute a coherent group with an average 


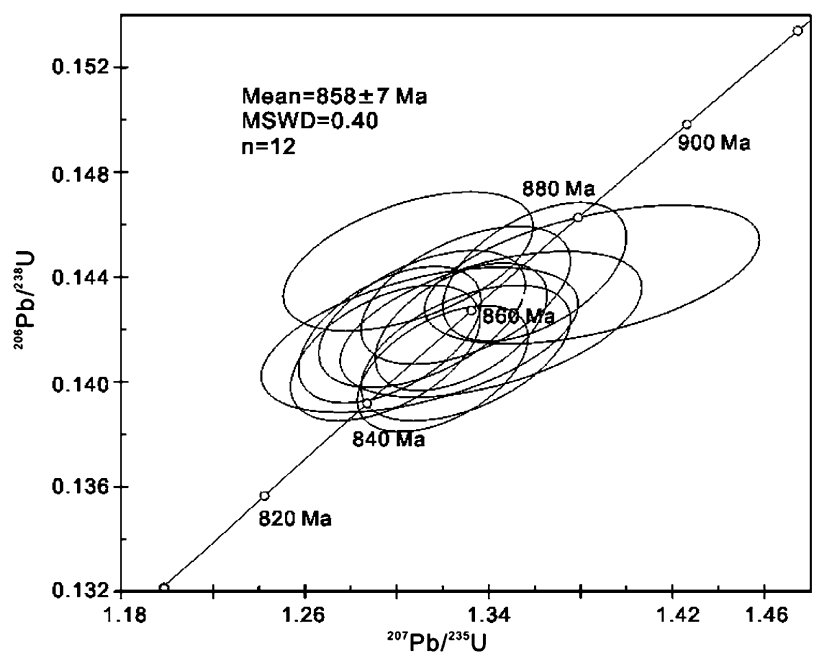

Figure 3. Concordia plot of SHRIMP U-Pb zircon dating results for the Guandaoshan pluton.

${ }^{206} \mathrm{~Pb} /{ }^{238} \mathrm{U}$ age of $858 \pm 7 \mathrm{Ma}$ in the concordia plot (fig. 3). This new age for the central diorite coincides with the age of $857 \pm 13 \mathrm{Ma}$ reported by $\mathrm{Li}$ et al. $(2003 b)$ for the marginal quartz diorite, indicating that they are probably comagmatic and crystallized at same time.

Whole-Rock Major and Trace Elements. Majorelement oxide concentrations were recalculated on a volatile-free basis. Rocks from the Guandaoshan pluton have $\mathrm{SiO}_{2}$ contents of $52.8-63.8 \mathrm{wt} \%$ and $\mathrm{Al}_{2} \mathrm{O}_{3}$ contents of $17.4-20.6 \mathrm{wt} \%$ (table Al, available in the online edition or from the Journal of Geology office). They have $\mathrm{MgO}$ contents of 1.31$5.97 \mathrm{wt} \%$ and $\mathrm{Mg}$ numbers (molar $\mathrm{Mg} /[\mathrm{Mg}+\mathrm{Fe}]$ ) of 35-52. Total alkalis $\left(\mathrm{Na}_{2} \mathrm{O}+\mathrm{K}_{2} \mathrm{O}\right)$ range from 2.66 to $4.53 \mathrm{wt} \%$, with much lower $\mathrm{K}_{2} \mathrm{O}$ contents (0.44-1.61 wt\%) than $\mathrm{Na}_{2} \mathrm{O}$ contents (2.14-3.74 $\mathrm{wt} \%$ ), and thus $\mathrm{K}_{2} \mathrm{O} / \mathrm{Na}_{2} \mathrm{O}$ ratios are much less than $1(0.17-0.56)$. On the total alkalis versus silica (TAS) classification diagram, the samples plot in the diorite, quartz diorite, and tonalite fields, except for six relatively felsic rocks (G8, 10, 17, 33, 43, and 44) that lie in the granodiorite field (fig. 4). Major-element variations are shown on Harker diagrams (fig. 5). According to the aluminum saturation index $(\mathrm{ASI} ; \mathrm{A} / \mathrm{CNK}=$ molar ratio $\mathrm{Al}_{2} \mathrm{O}_{3} /\left[\mathrm{CaO}+\mathrm{Na}_{2} \mathrm{O}+\mathrm{K}_{2} \mathrm{O}\right]$; Zen 1988; fig. 6), all but three samples are metaluminous (ASI $=$ $0.71-1.0)$, and these rocks are classified as calcalkaline granitoids with molar ratios $\mathrm{A} / \mathrm{NK}=$ $\mathrm{Al}_{2} \mathrm{O}_{3} /\left(\mathrm{Na}_{2} \mathrm{O}+\mathrm{K}_{2} \mathrm{O}\right)>1$ (Barbarin 1999). Similarly, in the classification of the modified alkalilime index $\left(\mathrm{Na}_{2} \mathrm{O}+\mathrm{K}_{2} \mathrm{O}-\mathrm{CaO}\right.$; Frost et al. 2001), they plot within the calcic granitoid field (fig. 7a). The Fe numbers $\left(\mathrm{Fe}_{2} \mathrm{O}_{3} /\left[\mathrm{Fe}_{2} \mathrm{O}_{3}+\mathrm{MgO}\right]\right.$; Frost et al. 2001) are typically below 0.8 and the samples all fall in the magnesian granitoid group (i.e., Cordilleran type; fig. $7 b$ ).

The Guandaoshan rocks are characterized by low total abundances of REEs (18.5-44.7 ppm) and have chondrite-normalized REE patterns slightly enriched in light REEs (LREEs), with $(\mathrm{La} / \mathrm{Yb})_{\mathrm{N}}=$ 1.3-3.5, and depleted in middle REEs (MREEs), with $(\mathrm{La} / \mathrm{Sm})_{\mathrm{N}}=1.1-2.3$ and $(\mathrm{Dy} / \mathrm{Lu})_{\mathrm{N}}=0.66-0.99$, resulting in slightly concave patterns (fig. 8a). Most samples have slightly positive $\mathrm{Eu}$ anomalies $\left(\mathrm{Eu} / \mathrm{Eu}^{*}=1.0-1.2\right)$.

All of the rocks from this pluton have relatively high Sr (380-770 ppm), Rb (7.8-28 ppm), and $\mathrm{Ba}$ (350-1100 ppm) contents and low Y (6.4-19 ppm) and $\mathrm{Nb}$ contents $(0.84-1.9 \mathrm{ppm})$. They also have moderate Ni (12-60 ppm) and $\mathrm{Cr}(2-135 \mathrm{ppm})$ contents (table A1). In the primitive mantle-normalized spidergram, all of the samples are significantly enriched in large-ion lithophile elements (LILEs) such as $\mathrm{Rb}, \mathrm{Ba}, \mathrm{Pb}$, and $\mathrm{Sr}$ and strongly depleted in high-field strength elements (HFSEs) such as $\mathrm{Nb}$, Ta, and Ti (fig. 8b).

Rb-Sr and Sm-Nd Isotopic Compositions. The diorites and quartz diorites have similar isotopic compositions, with $\varepsilon_{\mathrm{Nd}}(t)$ values of +3.9 to +5.1 and a narrow range of initial ${ }^{87} \mathrm{Sr} /{ }^{86} \mathrm{Sr}$ ratios, 0.7028 0.7033 , at $860 \mathrm{Ma}$ (table 2). In the diagram of $\varepsilon_{\mathrm{Nd}}(t)$ values versus initial ${ }^{87} \mathrm{Sr} /{ }^{86} \mathrm{Sr}$ ratios, the samples plot near the mantle array, indicative of a depletedmantle source (fig. 9).

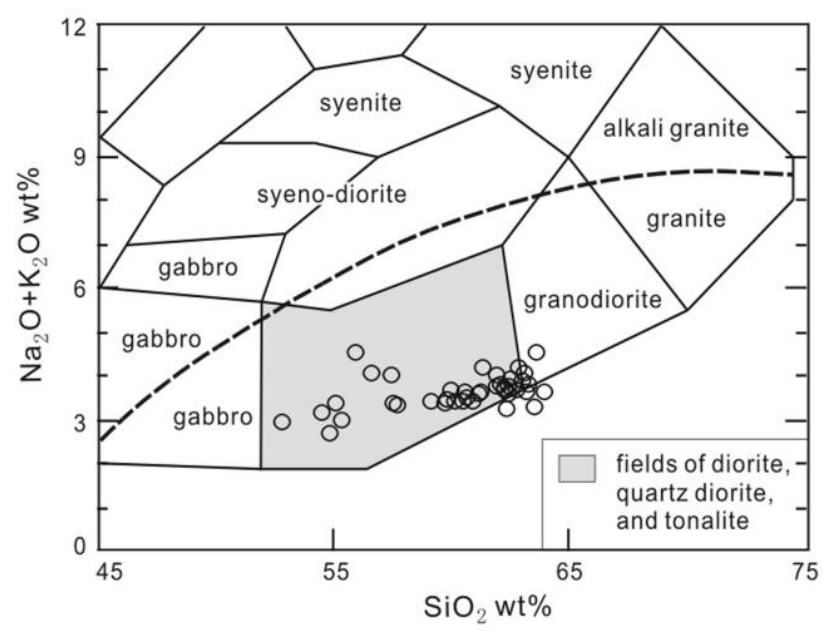

Figure 4. Total alkalis versus silica (TAS) diagram for classification of the Guandaoshan rocks (after Wilson 1989). 

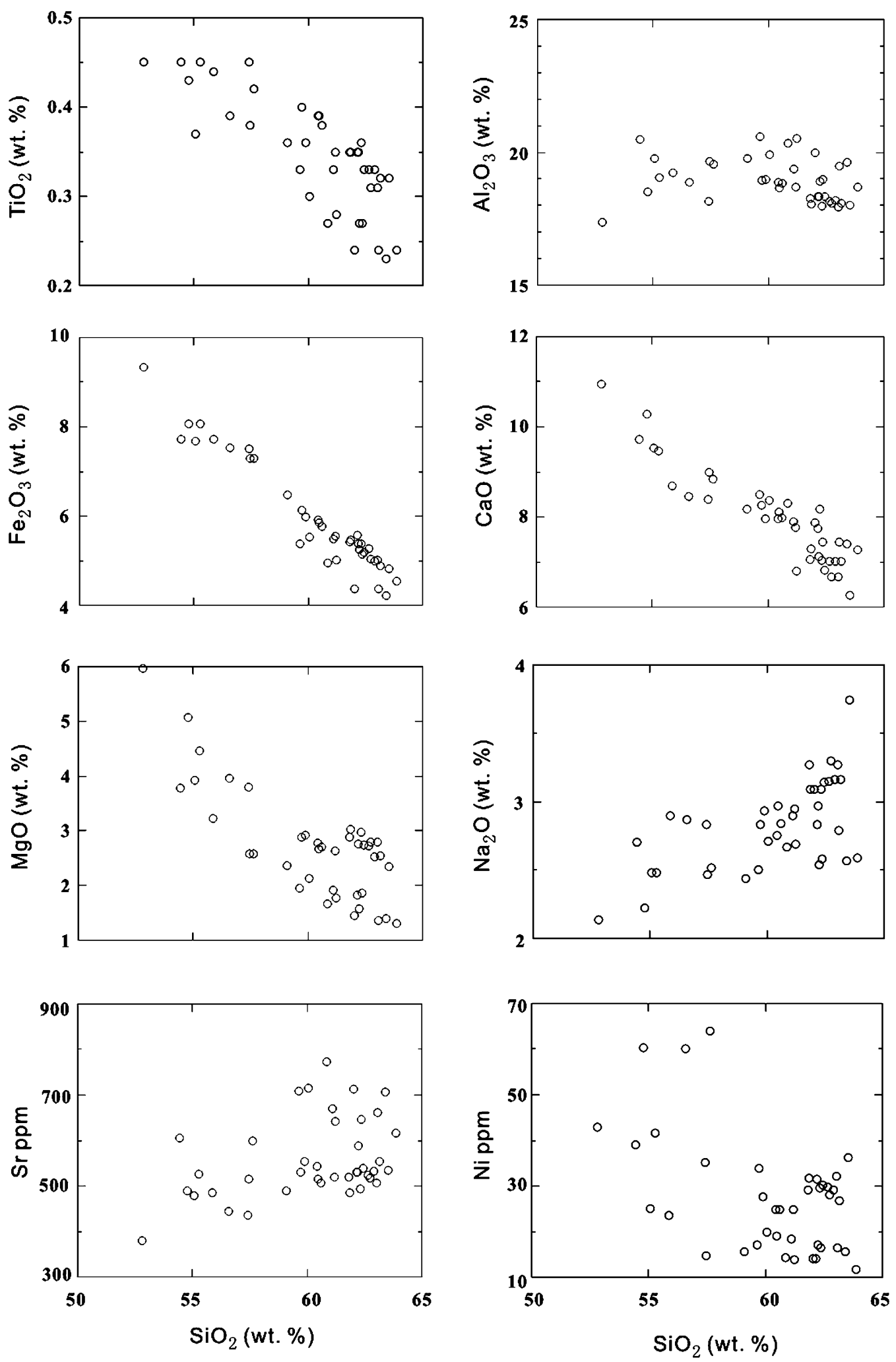

Figure 5. Selected oxide Harker plots for the Guandaoshan rocks. 


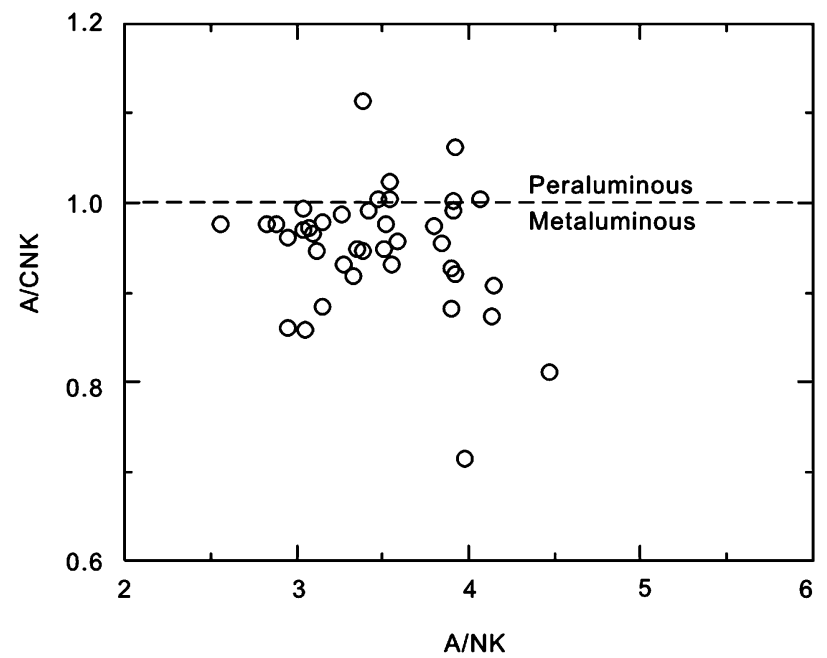

Figure 6. A/CNK versus A/NK plot showing the metaluminous nature of the Guandaoshan granitoids. $\mathrm{A}=$ $\mathrm{Al}_{2} \mathrm{O}_{3} ; \mathrm{CNK}=\mathrm{CaO}+\mathrm{Na}_{2} \mathrm{O}+\mathrm{K}_{2} \mathrm{O} ; \quad \mathrm{NK}=\mathrm{Na}_{2} \mathrm{O}+\mathrm{K}_{2} \mathrm{O}$ (all in molar proportion).

Zircon Lu-Hf Isotopes. Zircons from diorites and quartz diorites have a wide range of $\mathrm{Hf}$ isotopes, with ${ }^{176} \mathrm{Lu} /{ }^{177} \mathrm{Hf}$ ratios of $0.000485-0.006326$ and ${ }^{176} \mathrm{Hf} /{ }^{177} \mathrm{Hf}$ ratios of $0.282595-0.282794$ (table A2, available in the online edition or from the Journal of Geology office). The results show a single distribution in both initial $\mathrm{Hf}$ isotope ratios and $\mathrm{Hf}$ model ages. The initial ${ }^{176} \mathrm{Hf} /{ }^{177} \mathrm{Hf}$ ratios range from 0.282555 to 0.282734 , and $\varepsilon_{\mathrm{Hf}}$ values range from +11.3 to +17.7 , with a weighted mean of +14.0 (fig. 10a). One-stage Hf model ages range from 700 to $968 \mathrm{Ma}$, with a weighted mean of $857 \pm 9 \mathrm{Ma}$ (fig. 10b), almost identical to the crystallization age of $858 \pm 7 \mathrm{Ma}$.

\section{Discussion}

Classifying the Guandaoshan Dioritic Rocks. Granitoids can be classified using approximately 20 different classification schemes proposed over the past several decades (Barbarin 1999). Among these classifications, the most widely used is the alphabetic classification (I, S, A, M, and C; Clarke 1992; Frost et al. 2001). The rocks from the Guandaoshan pluton are metaluminous to weakly peraluminous (fig. $6)$ and relatively sodic. They have a wide range of silica contents (52.8-63.8 wt\%) but relatively uniform initial ${ }^{87} \mathrm{Sr} /{ }^{86} \mathrm{Sr}$ ratios of $\sim 0.703$ (fig. 9). Therefore, the Guandaoshan pluton belongs to either Itype (Chappell and White 1974) or M-type granitoids (White 1979; Pitcher 1983) in the alphabetic classification.
Based on mineral assemblages, petrographic and emplacement criteria, and aluminum saturation of granitic rocks, Barbarin (1999) proposed a synthetic classification in which the granitoids are divided into six rock types with certain geodynamic environments. Mineralogically, the Guandaoshan granitoids contain abundant amphibole ( 10-40 modal\%) and minor sphene and clinopyroxene. Geochemically, aside from three samples being mildly peraluminous (ASI $=1.0-1.1$, probably as a result of amphibole (ASI $<0.5)$ fractionation (Zen 1986), the rocks are calc-alkaline, with ASI $<1$ and A/NK $>1$ (fig. 6), and they have Fe numbers below 0.8 (fig. $7 b$ ). They are also characterized by low $\mathrm{K}$ and high Ca contents (table A1; fig. 5). Moreover,
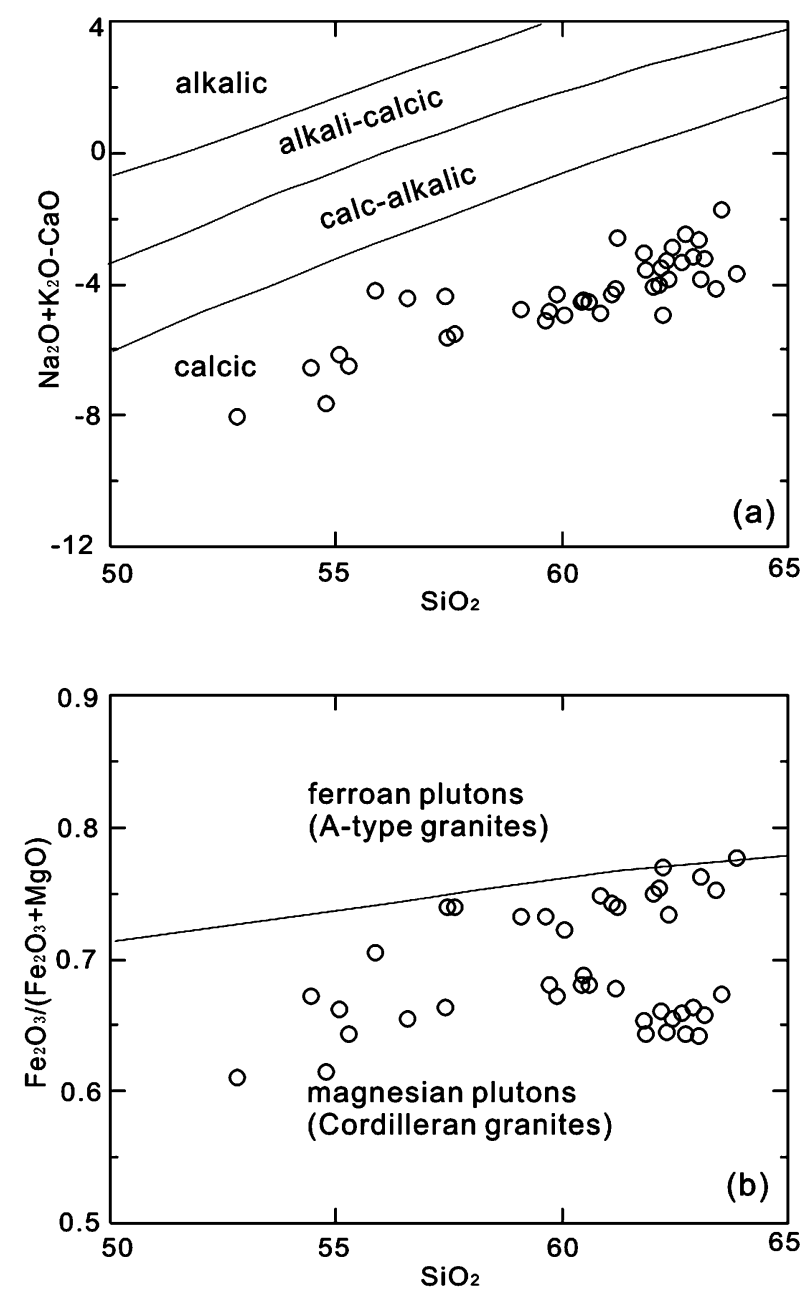

Figure 7. $a, \mathrm{Na}_{2} \mathrm{O}+\mathrm{K}_{2} \mathrm{O}-\mathrm{CaO}$ versus $\mathrm{SiO}_{2}$ wt $\%$ plot showing the calcic nature of the Guandaoshan rocks; $b$, $\mathrm{Fe}_{2} \mathrm{O}_{3} /\left(\mathrm{Fe}_{2} \mathrm{O}_{3}+\mathrm{MgO}\right)$ versus $\mathrm{SiO}_{2}$ wt $\%$ plot showing the similarity of the Guandaoshan rocks to Cordilleran granitoids (after Frost et al. 2001). 

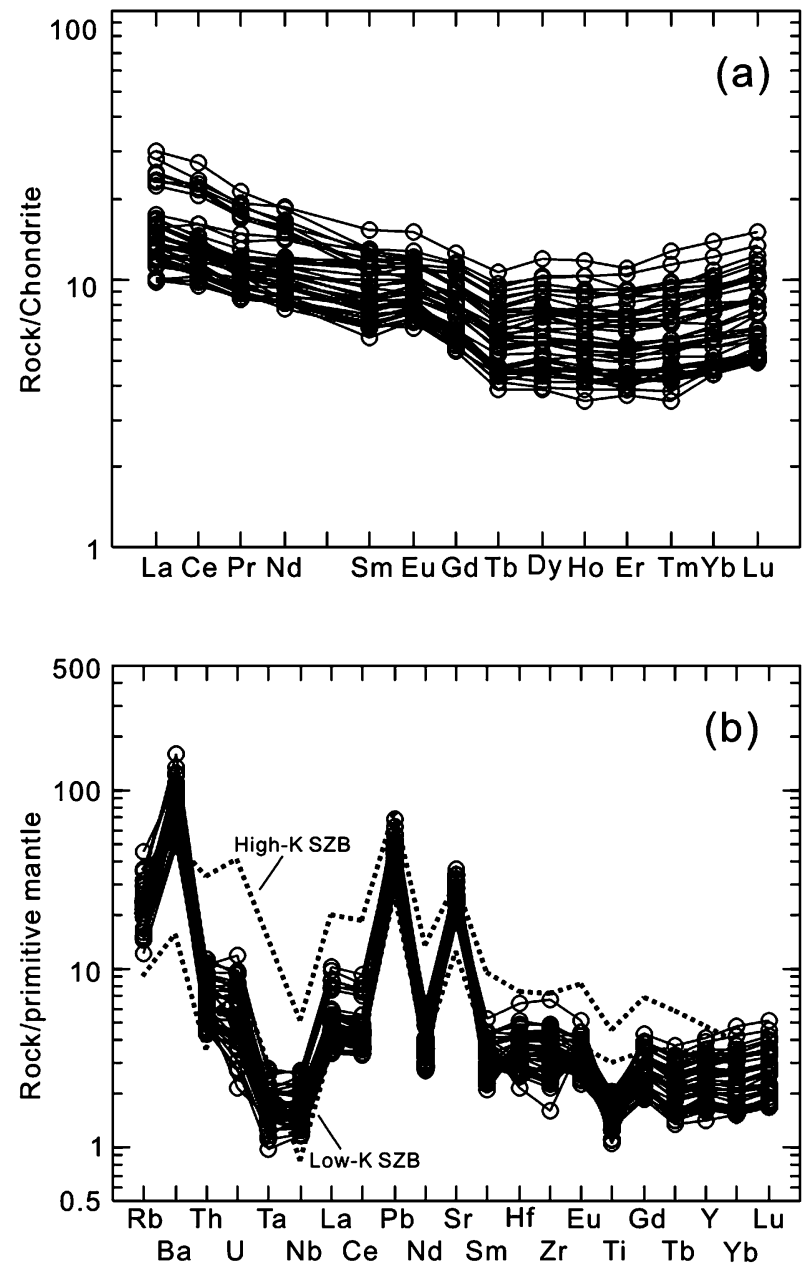

Figure 8. $a$, Chondrite-normalized rare earth element patterns; $b$, primitive mantle-normalized trace-element spider diagrams for the Guandaoshan rocks. Normalization values are from Sun and McDonough (1989). The "average" low- and high-K subduction zone basalt (SZB) compositions indicated by dotted lines are also shown for comparison (edited from Tatsumi and Eggins 1995).

mafic enclaves and mafic dikes are typically abundant in the pluton. All these features indicate that the Guandaoshan pluton is an amphibole-rich, calc-alkaline granitoid (ACG) in the classification of Barbarin (1999). Such rocks are called Cordilleran-type (or Andean-type) granitoids because they are the main components of the Cordilleran magmatism along the western margins of North and South America (Bateman 1992).

Frost et al. (2001) proposed another descriptive classification scheme for granitic rocks, based on three geochemical variables: Fe number, modified alkali-lime index, and aluminum saturation. According to this classification, the Guandaoshan di- oritic rocks plot in the magnesian granite field (i.e., Cordilleran granite field) rather than the ferroan granite field (i.e., A-type; fig. 7b). They further plot in the calcic and then metaluminous fields (figs. 6, $7 a$ ), in which the typical granitic rock types are plutons on the outboard portions of Cordilleran batholiths, in good agreement with the ACG classification for the Guandaoshan rocks.

Crustal versus Mantle Origin of the Guandaoshan Pluton. It is important to determine whether the Guandaoshan pluton was mantle or crust derived. Li et al. $(2003 b)$ suggested that the Guandaoshan pluton is an I-type granite, which led the authors to suggest that it was crust derived and formed by melting of mafic to intermediate igneous rocks. However, application of the I- and S-type criteria to magma origins is sometimes misleading (Brown et al. 1984; Barbarin 1999; Frost et al. 2001) because similar granitic compositions can be generated from partial melting of a variety of sources, and most granitoids are apparently produced from mixtures of mantle-derived mafic melts and melts of crustal rocks (Frost et al. 2001 and references therein). The compositions of I-type granites do not necessarily imply that the magmas actually originated from preexisting igneous rocks. A mantle origin for the Cordilleran granitoids was proposed by Brown (1977). Calc-alkaline granitoids commonly have a mixed origin with various proportions of crustal- and mantle-derived components, but the mantle component is typically dominant in most Ca-rich and K-poor varieties (Barbarin 1999 and references therein). In the well-studied Lachlan Fold Belt of Australia, most I-type granitoids are ACG varieties with mixed or mantle origins (Barbarin 1999).

The geochemistry of the Guandaoshan pluton points to a mantle origin rather than a crustal origin. Melting of the lower crust generally produces rocks with highly fractionated chondrite-normalized REE patterns and high $\mathrm{K}_{2} \mathrm{O}$ (typically $>1 \mathrm{wt} \%$ ), $\mathrm{Th}$, and $\mathrm{U}$ contents because of their incompatibilities during melting. In contrast, the Guandaoshan rocks show flat but slightly concave REE patterns and low $\mathrm{K}_{2} \mathrm{O}$ (mostly $<1 \mathrm{wt} \%$ ), Th, and $\mathrm{U}$ contents (fig. 8).

The metaluminous nature of the Guandaoshan rocks (fig. 6) also does not support an origin by melting of low-K tholeiites, which would typically generate peraluminous liquids, as documented by experimental studies (Holloway and Burnham 1972; Beard and Lofgren 1991; Rushmer 1991; Douce and Beard 1995). It is therefore very unlikely that the Guandaoshan rocks were derived from partial melting of juvenile crust. 
Table 2. Rb-Sr and Sm-Nd Isotopic Compositions of the Guandaoshan Pluton, SW China

\begin{tabular}{|c|c|c|c|c|c|c|c|c|c|c|c|}
\hline Sample & $\begin{array}{c}\mathrm{Rb} \\
(\mathrm{ppm})\end{array}$ & $\begin{array}{c}\mathrm{Sr} \\
\text { (ppm) }\end{array}$ & $\begin{array}{l}{ }^{87} \mathrm{Rb} / \\
{ }^{86} \mathrm{Sr}\end{array}$ & ${ }^{87} \mathrm{Sr} /{ }^{86} \mathrm{Sr} \pm 2 \sigma$ & $\begin{array}{l}{ }^{87} \mathrm{Sr} \\
{ }^{86} \mathrm{Sr}_{\mathrm{i}}\end{array}$ & $\begin{array}{c}\text { Sm } \\
\text { (ppm) }\end{array}$ & $\underset{(\mathrm{ppm})}{\mathrm{Nd}}$ & $\begin{array}{l}{ }^{147} \mathrm{Sm} / \\
{ }^{144} \mathrm{Nd}\end{array}$ & ${ }^{143} \mathrm{Nd} /{ }^{144} \mathrm{Nd} \pm 2 \sigma$ & $\begin{array}{l}{ }^{143} \mathrm{Nd} / \\
{ }^{144} \mathrm{Nd}_{\mathrm{i}}\end{array}$ & $\varepsilon_{\mathrm{Nd}}(t)$ \\
\hline & 12 & 55 & .063 & 0000 & & & & & 00013 & & 4.3 \\
\hline 1 & & & & & & & & & & & 4. \\
\hline & & & & & & & & & & & 3.9 \\
\hline 24 & & & & $8+00$ & & & & & & & 5.1 \\
\hline & & & & & & & & & & & 4.7 \\
\hline G46 & 13.78 & 627 & .064 & .000014 & .70292 & 1.74 & 7.51 & .1400 & $.512547 \pm .000013$ & 51176 & 4.5 \\
\hline
\end{tabular}

Note. Subscript i indicates initial isotope ratio.

Positive $\varepsilon_{\mathrm{Nd}}$ values $(+3.3$ to +5.2$)$ and low initial ${ }^{87} \mathrm{Sr} /{ }^{86} \mathrm{Sr}$ ratios $(0.7028-0.7033)$ of the Guandaoshan rocks favor direct derivation from the mantle (fig. 9). This interpretation is also supported by high zircon initial ${ }^{176} \mathrm{Hf} /{ }^{177} \mathrm{Hf}$ ratios of $0.282555-$ 0.282734 and $\varepsilon_{\mathrm{Hf}}(t)$ values of +11.3 to +17.7 (figs. $10,11)$, which are even higher than those of the mafic-ultramafic rocks reported thus far in the Panxi region, such as the Dadukou, Shaba, and Gaojiacun plutons, indicating a much depleted mantle (fig. 11). Moreover, the Hf model age can be used as a proxy for the minimum source age of the host magma from which the zircon crystallized (Zheng et al. 2006). One-stage Hf model ages should fall between the dates of emplacement of mantlederived magma and the formation of the involved crust. The youngest $T_{\mathrm{DM}}$ ages with the most positive $\varepsilon_{\mathrm{Hf}}(t)$ values represent the maximum ages of magma extraction from the coeval depleted mantle, whereas the oldest $T_{\mathrm{DM}}$ ages with the most negative $\varepsilon_{\mathrm{Hf}}(t)$ values represent the minimum ages of the crustal component. In the case of mantle-derived granitoids, the model age gives the time of mantle fractionation of the basaltic precursor to the rocks. The similarity between the SHRIMP zircon U-Pb age $(858 \pm 7 \mathrm{Ma})$ and the $T_{\mathrm{DM}}$ age $(857 \pm 9 \mathrm{Ma})$ for the Guandaoshan pluton with highly positive $\varepsilon_{\mathrm{Hf}}(t)$ values clearly indicates derivation from a depleted mantle.

Crustal Assimilation and Fractional Crystallization. The intermediate composition of the Guandaoshan pluton can be explained by crustal assimilation or by crystal fractionation. Assimilation combined with fractional crystallization is an important process during evolution of mantle-derived magmas (usually basaltic melts) and may modify both elemental and isotopic compositions. Crustal contamination generally increases LILEs, $\mathrm{K}_{2} \mathrm{O}$, and $\mathrm{Na}_{2} \mathrm{O}$ contents and decreases $\mathrm{P}_{2} \mathrm{O}_{5}$ and $\mathrm{TiO}_{2}$ contents. The co-variations of $\mathrm{TiO}_{2}$ and $\mathrm{P}_{2} \mathrm{O}_{5}$ with $\mathrm{SiO}_{2}$, low to moderate concentrations of $\mathrm{K}_{2} \mathrm{O}$ and $\mathrm{Na}_{2} \mathrm{O}$ (fig. 5), and very low $\mathrm{K}_{2} \mathrm{O} / \mathrm{Na}_{2} \mathrm{O}$ ratios $(0.17-0.56)$ in the Guandaoshan rocks suggest dominance of fractionation with only minimal crustal contami- nation. Crustal contamination should result in negative $\mathrm{Nb}$-Ta and positive $\mathrm{Zr}$-Hf anomalies. Thus the absence of positive $\mathrm{Zr}$-Hf anomalies in most Guandaoshan rocks also indicates that crustal contamination was not important (fig. 8b), which is consistent with the narrow range of positive $\varepsilon_{\mathrm{Nd}}(t)$ values $(+3.3$ to +5.2$)$ and low initial ${ }^{87} \mathrm{Sr} /{ }^{86} \mathrm{Sr}$ ratios (0.7028-0.7033) for the Guandaoshan rocks (fig. 9).

Rocks of the Guandaoshan pluton show a continuous evolutionary trend from diorite through quartz diorite/tonalite to granodiorite. They form mostly linear correlations in Harker diagrams (fig. 5), indicating that fractional crystallization played a major role in their evolution. The negative correlations between $\mathrm{MgO}$ and $\mathrm{SiO}_{2}$ suggest fractionation of olivine and/or clinopyroxene, which variably decreases $\mathrm{Mg}, \mathrm{Cr}$, and $\mathrm{Ni}$, as seen in the Guandaoshan rocks. The absence of negative Eu anomalies in the chondrite-normalized REE patterns and positive correlations of $\mathrm{Na}_{2} \mathrm{O}$ and $\mathrm{Sr}$ with $\mathrm{SiO}_{2}$ argue against plagioclase fractionation. Well-

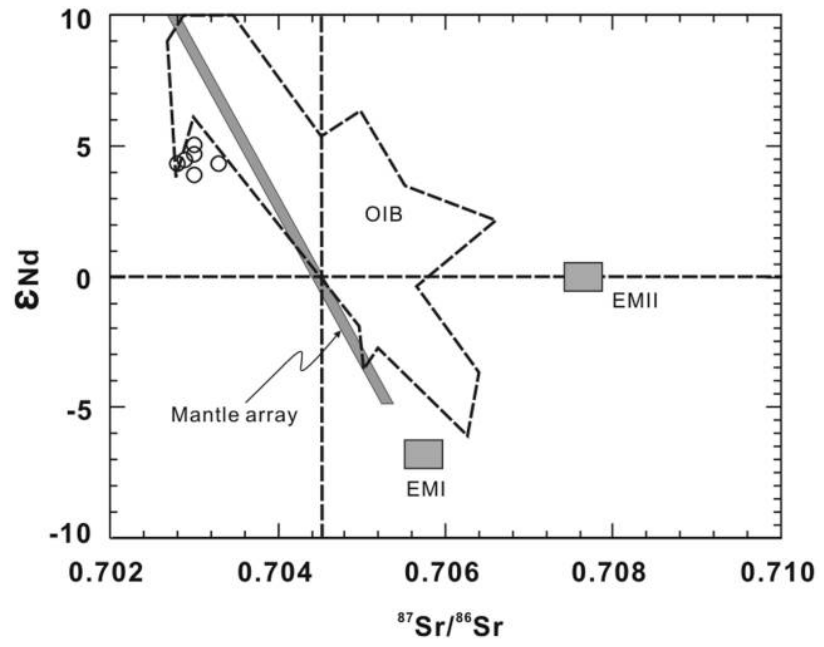

Figure 9. Plots of ${ }^{87} \mathrm{Sr} /{ }^{86} \mathrm{Sr}$ versus $\varepsilon_{\mathrm{Nd}}(t)$ for the Guandaoshan rocks. Ocean island basalt (White and Duncan 1996) and enriched mantle EMI and EMII members (Hart 1988) are also shown for comparison. 

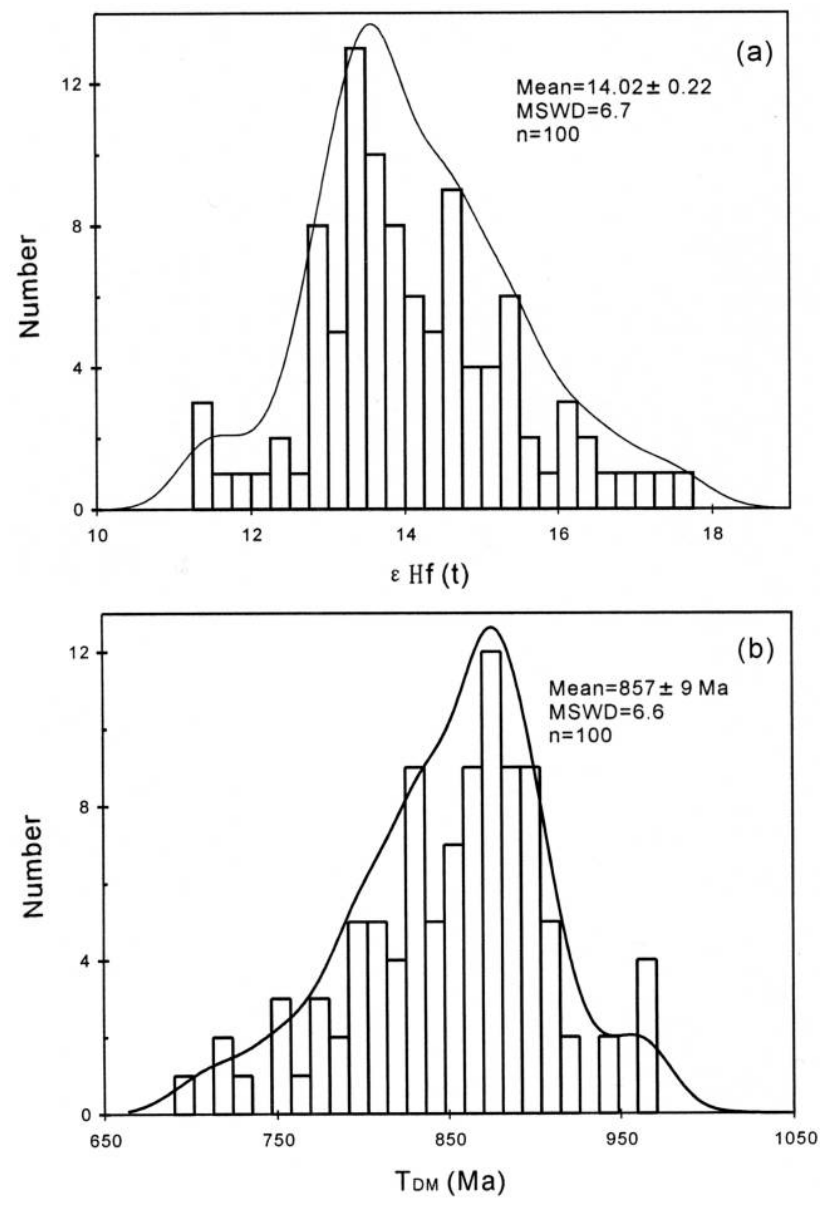

Figure 10. Initial Hf isotope ratios $(a)$ and single-stage Hf model ages $(b)$ calculated at $t=860 \mathrm{Ma}$ for zircons from four samples $(\mathrm{G} 11,25,38$, and 48) of the Guandaoshan pluton (Ludwig 1999).

defined negative correlations of $\mathrm{TiO}_{2}$ and $\mathrm{Fe}_{2} \mathrm{O}_{3}$ with $\mathrm{SiO}_{2}$ probably suggest fractionation of $\mathrm{Fe}-\mathrm{Ti}$ oxides (e.g., rutile and ilmenite), an interpretation supported by the strong negative $\mathrm{Nb}$ and $\mathrm{Ta}$ anomalies relative to La (fig. 8b; Foley et al. 2000).

The slightly concave REE patterns of the Guandaoshan rocks (fig. 8a) indicate that a relatively large amount of amphibole fractionation may dominate the bulk partition coefficient for this range of elements because amphibole preferentially incorporates MREEs over heavy REEs (HREEs; Romick et al. 1992; Rollinson 1993; Davidson et al. 2007). This interpretation is in good agreement with the field observation of amphibole accumulation (fig. $2 c)$. On the other hand, extensive amphibole fractionation may also result in a high $\mathrm{La} / \mathrm{Yb}$ ratio of the residual melt (Romick et al. 1992 and references therein). The low $\mathrm{La} / \mathrm{Yb}$ ratios $(1.8-4.8)$ of the
Guandaoshan rocks may suggest that the removal of some accessory mineral (e.g., allanite), with extremely high distribution coefficients for LREEs over HREEs (Rollinson 1993), has effectively decreased the $\mathrm{La} / \mathrm{Yb}$ ratios in the magma. The Guandaoshan pluton has relatively high $\mathrm{Sr}(>\sim 400 \mathrm{ppm})$, low Y ( 10.6 ppm), and, thus, high Sr/Y ratios, ranging from 28 to 106. The high Sr contents of the Guandaoshan rocks probably reflect the absence of plagioclase fractionation, and the low Y contents argue for amphibole fractionation during the magma evolution.

Amphibole fractionation was most likely the dominant process of magma evolution in the Guandaoshan pluton, which is consistent with development of intermediate magma by amphibolecontrolled fractionation of basaltic magma (Cawthorn and O'Hara 1976). Removal of crystallizing amphibole phase (approximately 38-42 wt $\% \mathrm{SiO}_{2}$ ) will cause a rapid enrichment in $\mathrm{SiO}_{2}$, even with a relatively small proportion of crystallization (Cawthorn and O'Hara 1976). In addition, because amphibole contains significantly more $\mathrm{TiO}_{2}$ than basalt (Davidson et al. 2007), amphibole fractionation can also efficiently drive liquid compositions to lower $\mathrm{TiO}_{2}$ contents, an effect similar to that of fractionation of Fe-Ti oxides.

Implications for the Neoproterozoic Arc Magmatism in South China. Cordilleran-type granitoids are thought to occur at active continental margins (Pitcher 1983, 1997; Barbarin 1999). The calc-alkaline granitoids are common in convergent margins and usually form vast batholiths that extend over hundreds of kilometers parallel to the continental margin (Pitcher 1983, 1997; Barbarin 1999). Thus, identification of the Guandaoshan pluton as a Cordilleran-type granitoid supports a subductionrelated tectonic environment and thus an Andeantype continental margin along the western margin of the Yangtze Block.

The Guandaoshan rocks have trace-element abundances lying between those of low-K tholeiites and high-K calc-alkaline basalts (fig. $8 b$ ). In tectonic discrimination diagrams (figs. 12, 13), they fall within the field of volcanic arc granite, significantly different from syncollisional granites, ocean ridge granites, and within-plate granites. The mantle origin of the Guandaoshan pluton strongly argues against the previous explanation that the arc features were inherited from previously existing arc rocks in the lower crust (Li et al. 2003b).

The mantle wedge above a subduction zone is usually metasomatized by slab-derived fluids enriched in LILEs but relatively depleted in HFSEs, accounting for the characteristic LILE enrichment 


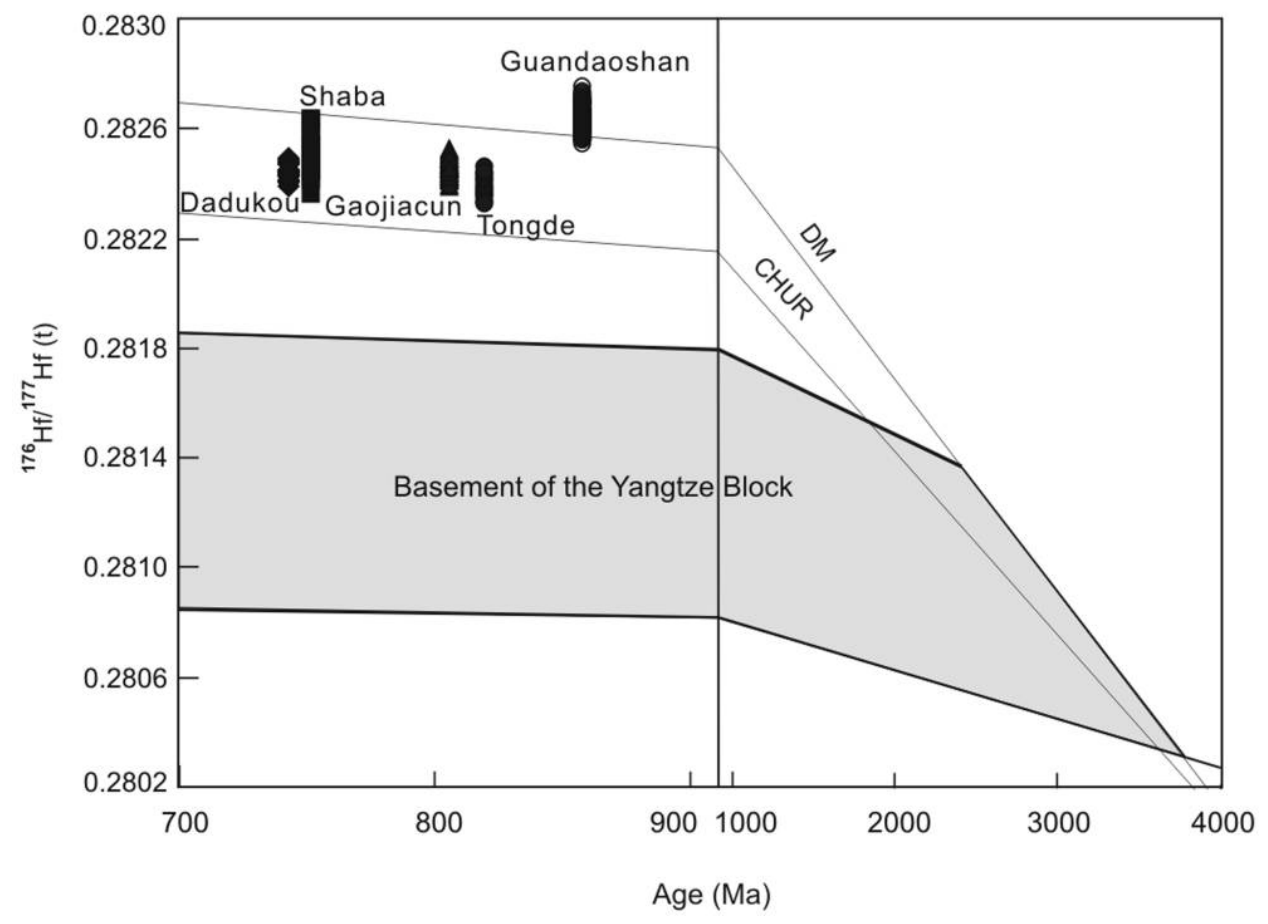

Figure 11. Initial Hf isotope compositions at the crystallization age of the zircons for the rocks from the Guandaoshan pluton. Data for the Neoproterozoic mafic-ultramafic Dadukou, Shaba, Gaojiacun, and Tongde plutons in the Panxi region and field for basement of the Yangtze Block are from Zhao et al. (2008). Reference lines representing meteoritic Hf evolution (CHUR) and the depleted mantle (DM) are from Blichert-Toft and Albarede (1997) and Griffin et al. (2000), respectively.

and HFSE depletion of classic arc magmas (Tatsumi and Nakamura 1986; Tatsumi et al. 1986; Hawkesworth et al. 1993; Woodhead et al. 1993; Pearce and Peate 1995). The Guandaoshan rocks are enriched in LILEs such as $\mathrm{Rb}, \mathrm{Ba}$, and $\mathrm{Sr}$ but depleted in HFSEs such as $\mathrm{Nb}, \mathrm{Ta}$, and $\mathrm{Ti}$ (fig. $8 b$ ), indicative of a subduction zone environment. Furthermore, extensive amphibole fractionation in the Guandaoshan rocks is consistent with the high water contents typical of primitive magmas above subduction zones (Fischer and Marty 2005; Wallace 2005).

The Guandaoshan pluton was previously interpreted as the earliest magmatic record of a proposed mantle superplume (Li et al. 2003b). However, this pluton is a typical Cordilleran-type granitoid occurring in a subduction zone, which does not support the view that the Neoproterozoic magmatism was associated with a mantle superplume and that the intermediate rocks were produced by magma mixing (Li et al. 1995, 1999, 2003b, 2003c). Moreover, mantle plumes typically produce large volumes of tholeiitic basalt with no intermediate melts and with only small volumes of silicic material $(<10 \%$; Wilson 1989). In contrast, Neopro- terozoic mafic rocks are sparse and silicic rocks are dominant in South China (Li et al. 2003c, 2006). There are more than 60 Neoproterozoic silicic to intermediate plutons (Shen et al. 2000) but only about 10 much smaller mafic-ultramafic intrusions (Zhu et al. 2004). In addition, the age spectrum of the Neoproterozoic magmatism in South China also poses a serious problem for the plume model. The two magmatic episodes that have been recognized ( 760-750 and 860-850 Ma) differ by about $100 \mathrm{~m}$.yr. and would require two major periods of mantle plume activity.

Our study of the $260-\mathrm{Ma}$ Guandaoshan pluton favors an arc origin of the Neoproterozoic magmatism (Zhou et al. 2002a, 2002b, 2006a, 2006b). Several other contemporaneous plutons with typical arc features have been reported along the western margin of the Yangtze Block, including the Qiaotou mafic pluton (853 $\pm 42 \mathrm{Ma}$; Shen et al. 2002) and the felsic Gongcai (864 $\pm 8 \mathrm{Ma}$ ) and Gezong plutons $(864 \pm 26 \mathrm{Ma}$; Zhou et al. 2002b). In the Yanbian region, the $820-810-M a$ Tongde pluton, the 810-Ma Gaojiacun and Lengshuiqing gabbroic intrusions (Shen et al. 2003; Zhou et al. 2006a), and 
the 740-Ma Panzhihua gabbroic pluton (Zhao and Zhou 2007a) are thought to be subduction related. In addition, more recently identified adakitic plutons, such as the 750 -Ma Xuelongbao (Zhou et al. 2006b) and the $760-\mathrm{Ma}$ Datian and Datianshan plutons (Zhao and Zhou 2007b), are also strong evidence of arc magmatism. These arc-related plutons define a major continental arc called the HannanPanxi arc (Zhou et al. 2002a, 2002b). This arc probably commenced at least at $\sim 900 \mathrm{Ma}$ and lasted $\sim 160$ m.yr. Arc volcanic rocks in the Xixiang Group in the Hannan region dated at $\sim 900$ Ma may record the earliest arc magmatism in the region (Ling et al. 2003). The unconformable contact between the
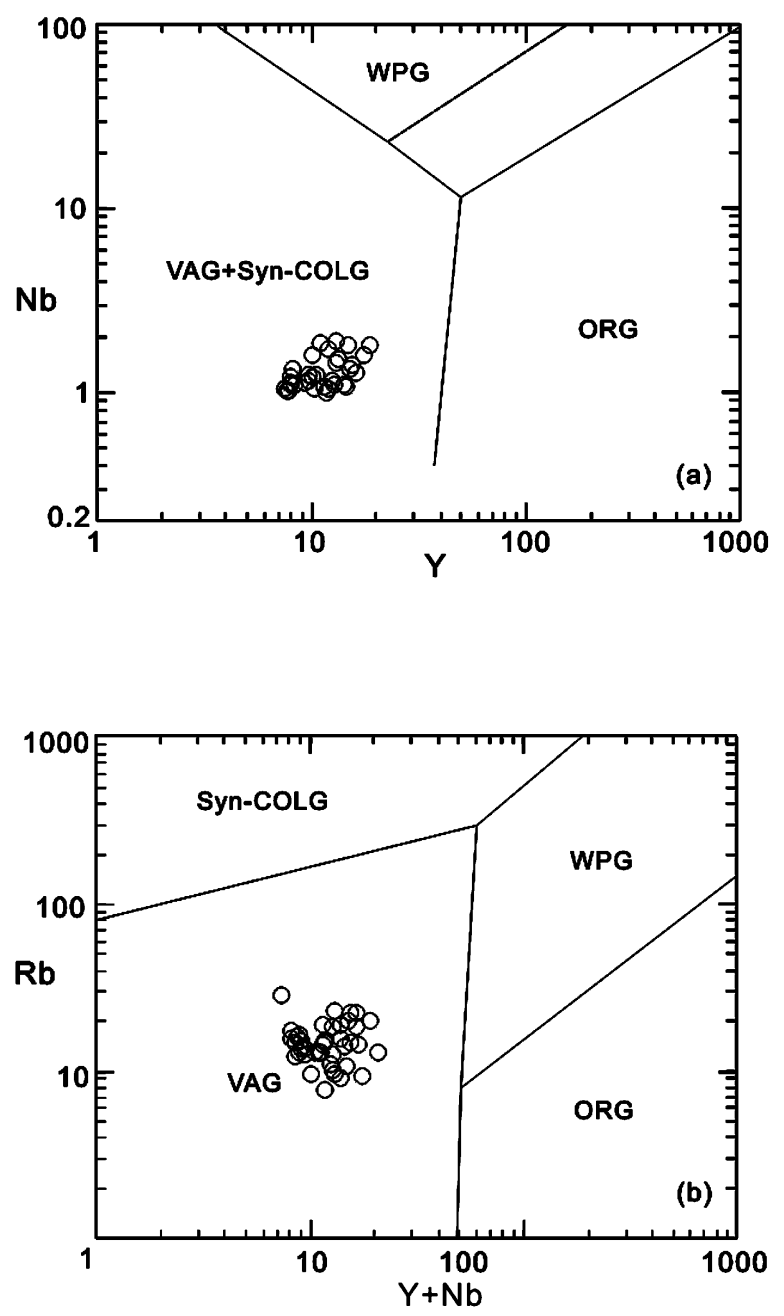

Figure 12. $\mathrm{Nb}-\mathrm{Y}(a)$ and $\mathrm{Rb}-(\mathrm{Y}+\mathrm{Nb})(b)$ discrimination diagrams for the Guandaoshan rocks (after Pearce et al. 1984). Syn-COLG = syncollisional granites, $V A G=$ volcanic-arc granites, $W P G=$ within-plate granites, $O R G=$ ocean-ridge granites.

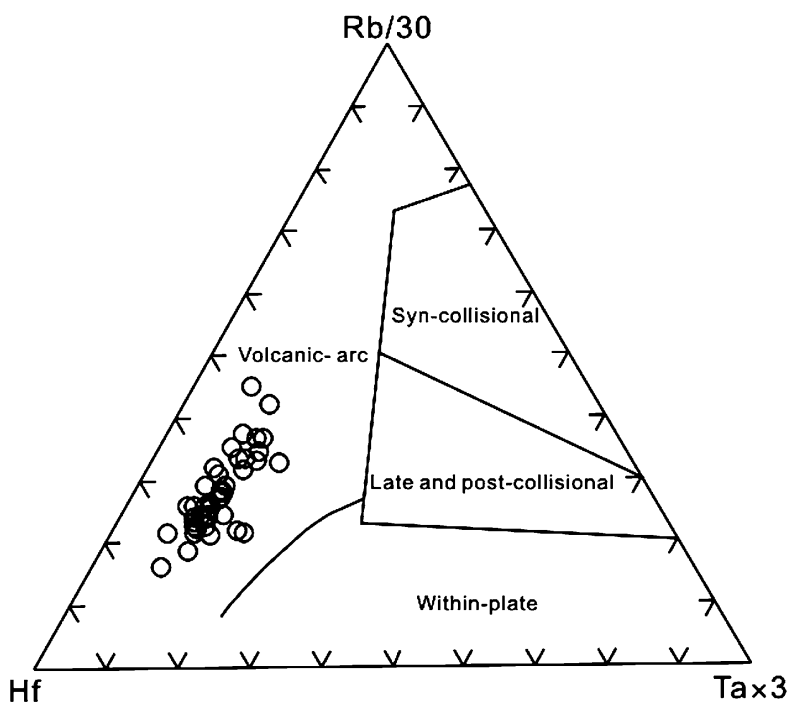

Figure 13. Hf-Rb/30-Ta $\times 3$ discrimination diagram for the Guandaoshan rocks (after Harris et al. 1986).

Sinian strata and the underlying Yanbian Group may mark termination of the major arc.

In addition, the widespread occurrence of subduction-related igneous rocks with a continuous age spectrum of $\sim 750-860 \mathrm{Ma}$ supports a major period of continental growth along the western margin of the Yangtze Block in a subduction zone environment. Subduction zones are favorable sites for continental accretion (Condie and Chomiak 1996). For example, the bulk of Cordilleran granitic rocks were clearly part of a Mesozoic-Cenozoic crustal accretion process; their source materials were largely and ultimately derived from the mantle (Pitcher 1997; Barbarin 1999). Similarly, the 860$\mathrm{Ma}$, mantle-derived, Cordilleran-type Guandaoshan pluton, which has Hf model ages in good agreement with the timing of zircon crystallization from the magmas (fig. 10b), suggests a major growth of juvenile crust along the western margin of the Yangtze Block.

\section{Conclusions}

The 860-Ma Guandaoshan dioritic pluton is an amphibole-rich, calc-alkaline, Cordilleran-type granitoid. It was derived from a mantle source modified by slab-derived fluids above a subduction zone. Amphibole fractionation produced dioritic compositions and thus played a major role in the magma evolution. Voluminous arc-related magmatism ( 900-740 Ma) along the western margin 
of the Yangtze Block formed the Neoproterozoic Hannan-Panxi magmatic belt, indicating an Andean-type continental margin rather than a mantle plume-related rift setting.

\section{A C K N O W L E D G M E N T S}

This work was financially supported by the National Science Foundation of China (grant 40672037/D0204), the Chinese Education Minis- try 111 project (B07011), and the International Innovation Partnership Program of the Chinese Academy of Sciences and the State Administration of Foreign Experts Affairs. We wish to thank X. Fu, L. Qi, Y. Yang, X. Zhao, and Q. Guo for help with the analyses. We are grateful to P. Robinson, F. Wu, and J. Zhao for reading an earlier draft, which resulted in substantial improvement of this article. We acknowledge two anonymous reviewers for their helpful and constructive comments.

\section{R E F E R E N C E S C I T E D}

Barbarin, B. 1999. A review of the relationships between granitoid types, origins and their geodynamic environments. Lithos 46:605-626.

Bateman, P. C. 1992. Plutonism in the central part of the Sierra Nevada Batholith, California. U.S. Geol. Surv. Prof. Pap. 1483.

Beard, J. S., and Lofgren, G. E. 1991. Dehydration melting and water-saturated melting of basaltic and andesitic greenstones and amphibolites at 1, 3, and $6.9 \mathrm{~kb}$. J. Petrol. 32:365-401.

BGMRSP (Bureau of Geology and Mineral Resources of the Sichuan Province). 1972. Regional geological survey of People's Republic of China, the Yanbian Sheet (G47-XII; geological part) map and report, scale $1: 200,000$ (in Chinese).

Blichert-Toft, J., and Albarede, F. 1997. The Lu-Hf geochemistry of the chondrites and the evolution of the mantle-crust system. Earth Planet. Sci. Lett. 148:243258.

Brown, G. C. 1977. Mantle origin of Cordilleran granites. Nature 265:21-24.

Brown, G. C.; Thorpe, G. C.; and Webb, P. C. 1984. The geochemical characteristics of granitoids in contrasting arcs and comments on magma sources. J. Geol. Soc. Lond. 141:413-426.

Cawthorn, R. G., and O'Hara, M. J. 1976. Amphibole fractionation in calc-alkaline magma genesis. Am. J. Sci. 276:309-329.

Chappell, B. W., and White, A. J. R. 1974. Two contrasting granite types. Pac. Geol. 8:173-174.

Clarke, D. B. 1992. Granitoid rocks. London, Chapman \& Hall, $283 \mathrm{p}$.

Condie, K. C., and Chomiak, B. 1996. Continental accretion: contrasting Mesozoic and Early Proterozoic tectonic regimes in North America. Tectonophysics 265:101-126.

Davidson, J.; Turner, S.; Handley, H.; Macpherson, C.; and Dosseto, A. 2007. Amphibole "sponge" in arc crust? Geology 35:787-790.

Douce, A. E. P., and Beard, J. S. 1995. Dehydration-melting of biotite gneiss and quartz amphibolite from 3 to 15 kbar. J. Petrol. 36:707-738.

Druschke, P.; Hanson, A. D.; Yan, Q.; Wang, Z.; and Wang, T. 2006. Stratigraphic and U-Pb SHRIMP de- trital zircon evidence for a Neoproterozoic continental arc, Central China: Rodinia implications. J. Geol. 114:627-636.

Du, L. L.; Geng, Y. S.; Yang, C. H.; Wang, X. S.; Ren, L. D.; Zhou, X. W.; Shi, Y. Y.; and Yang, Z. S. 2005. Geochemistry and SHRIMP U-Pb zircon chronology of basalts from the Yanbian group in the western Yangtze block. Acta Geol. Sin. 76:805-813 (in Chinese with English abstract).

Fischer, T. P., and Marty, B. 2005. Volatile abundances in the sub-arc mantle: insights from volcanic and hydrothermal gas discharges. J. Volcanol. Geotherm. Res. 140:205-216.

Foley, S. F.; Barth, M. G.; and Jenner, G. A. 2000. Rutile/ melt partition coefficients for trace elements and an assessment of the influence of rutile on the trace element characteristics of subduction zone magmas. Geochim. Cosmochim. Acta 64:933-938.

Frost, B. R.; Barnes, C. G.; Collins, W. J.; Arculus, R. J.; Ellis, D. J.; and Frost, C. D. 2001. A geochemical classification for granitic rocks. J. Petrol. 42:2033-2048.

Griffin, W. L.; Pearson, N. J.; Belousova, E.; Jackson, S. E.; van Achterbergh, E.; O'Reilly, S. Y.; and Shee, S. R. 2000. The Hf isotope composition of cratonic mantle: LAM-MC-ICPMS analysis of zircon megacrysts in kimberlites. Geochim. Cosmochim. Acta 64:133-147.

Guo, L. Z.; Lu, H. F.; Shi, Y. S.; Ma, R. S.; Sun, Y.; Shu, L. H.; Jia, D.; Zhang, Q. L.; Charvet, J.; and Faure, M. 1996. On the Meso-Neoproterozoic Jiangnan island arc: its kinematics and dynamics. Geol. J. China Univ. 2:1-13 (in Chinese with English abstract).

Harris, N. B. W.; Pearce, J. A.; and Tindle, A. G. 1986. Geochemical characteristics of collision-zone magmatism. In Coward, M. P., and Reis, A. C., eds. Collision tectonics. Geol. Soc. Spec. Publ. 19:67-81.

Hart, S. R. 1988. Heterogeneous mantle domains: signature, genesis and mixing chronologies. Earth Planet. Sci. Lett. 90:273-296.

Hawkesworth, C. J.; Gallagher, K.; Hergt, J. M.; and McDermott, F. 1993. Mantle and slab contributions in arc magmas. Annu. Rev. Earth Planet. Sci. 21:175204.

Holloway, J. R., and Burnham, C. W. 1972. Melting re- 
lations of basalt with equilibrium water pressure less than total pressure. J. Petrol. 13:1-29.

Jian, P.; Liu, D. Y.; and Sun, X. M. 2003. SHRIMP dating of Carboniferous Jinshajiang ophiolite in western Yunnan and Sichuan: geochronological constraints on the evolution of the Paleo-Tethys oceanic crust. Acta Geol. Sin. 77:217-228 (in Chinese with English abstract).

Li, X. H.; Li, Z. X.; Ge, W. C.; Zhou, H. W.; Li, W. X.; Liu, Y.; and Wingzte, T. D. 2003a. Neoproterozoic granitoids in South China: crystal melting above a mantle plume at ca. $825 \mathrm{Ma}$ ? Precambrian Res. 122: $45-83$.

Li, X. H.; Li, Z. X.; Sinclair, J. A.; Li, W. X.; and Carter, G. 2006. Revisiting the "Yanbian Terrane": implications for Neoproterozoic tectonic evolution of the western Yangtze Block, South China. Precambrian Res. 151:14-30.

Li, X. H.; Li, Z. X.; Zhou, H. W.; Liu, Y.; and Kinny, P. D. 2002. U-Pb zircon geochronology, geochemistry and Nd isotopic study of Neoproterozoic bimodal volcanic rocks in the Kangdian rift of South China: implications for the initial rifting of Rodinia. Precambrian Res. 113:135-154.

Li, X. H.; Li, Z. X.; Zhou, H. W.; Liu, Y.; Liang, X. R.; and Li, W. X. 2003b. SHRIMP U-Pb zircon age, geochemistry and $\mathrm{Nd}$ isotope of the Guandaoshan pluton in SW Sichuan: petrogenesis and tectonic significance. Sci. China D 46(suppl.):73-83.

Li, Z. X.; Li, X. H.; Kinny, P.; and Wang, J. 1999. The breakup of Rodinia: did it start with a mantle plume beneath South China? Earth Planet. Sci. Lett. 173:171181.

Li, Z. X.; Li, X. H.; Kinny, P. D.; Wang, J.; Zhang, S.; and Zhou, H. 2003c. Geochronology of Neoproterozoic syn-rift magmatism in the Yangtze craton, South China and correlations with other continents: evidence for a mantle superplume that broke up Rodinia. Precambrian Res. 122:85-109.

Li, Z. X.; Zhang, L.; and Powell, C. M. 1995. South China in Rodinia: part of the missing link between Australia-East Antarctica and Laurentia? Geology 23:407410.

Ling, W. L.; Gao, S.; Zhang, B. R.; Li, H. M.; Liu, Y.; and Cheng, J. P. 2003. Neoproterozoic tectonic evolution of the northwestern Yangtze craton, South China: implications for amalgamation and break-up of the Rodinia Supercontinent. Precambrian Res. 122:111-140.

Ludwig, K. R. 1999. Isoplot/Ex, version 2.06: a geochronological tool kit for Microsoft Excel. Spec. Publ. 1a. Berkeley, Berkeley Geochronology Center.

Pearce, J. A.; Harris, N. B. W.; and Tindle, A. G. 1984. Trace element discrimination diagrams for the tectonic interpretation of granitic rocks. J. Petrol. 25:956983.

Pearce, J. A., and Peate, D. W. 1995. Tectonic implications of the composition of volcanic arc magmas. Annu. Rev. Earth Planet. Sci. 23:251-285.

Pitcher, W. S. 1983. Granite type and tectonic environ- ment. In Hsu, K., ed. Mountain building processes. London, Academic Press, p. 19-40.

. 1997. The nature and origin of granite. London, Chapman \& Hall, 387 p.

Qi, L.; Hu, J.; and Gregoire, D. C. 2000. Determination of trace elements in granites by inductively coupled plasma-mass spectrometry. Talanta 51:507-513.

Rollinson, H. R. 1993. Using geochemical data: evaluation, presentation, interpretation. Harlow, UK, Addison Wesley Longman, $352 \mathrm{p}$.

Romick, J. D.; Kay, S. M.; and Kay, R. W. 1992. The influence of amphibole fractionation on the evolution of calc-alkaline andesite and dacite tephra from the central Aleutians, Alaska. Contrib. Mineral. Petrol. 112:101-118.

Rushmer, T. 1991. Partial melting of two amphibolites: contrasting experimental results under fluid-absent conditions. Contrib. Mineral. Petrol. 107:41-59.

SBGMR (Sichuan Bureau of Geology and Mineral Resources). 1991. Regional geology of Sichuan Province. Geol. Mem. 23. Beijing, Geological Publishing House, 730 p. (in Chinese with English summary).

Shen, W. Z.; Gao, J. F.; Xu, S. J.; Tan, G. Q.; Yang, Z. S.; and Yang, Q. W. 2003. Age and geochemical characteristics of the Lengshuiqing body, Yanbian, Sichuan Province. Acta Petrol. Sin. 19:27-37 (in Chinese with English abstract).

Shen, W. Z.; Gao, J. F.; Xu, S. J.; and Zhou, G. Q. 2002. Geochemical characteristics and genesis of the Qiaotou basic complex, Luding County, eastern Yangtze Block. Geol. J. Univ. 8:380-389 (in Chinese with English abstract).

Shen, W. Z.; Li, H. M.; Xu, S. J.; and Wang, R. C. 2000. $\mathrm{U}-\mathrm{Pb}$ chronological of zircons from the Huangcaoshan and Xiasuozi granites in the western margin of Yangtze Plate. Geol. J. Univ. 6:412-416 (in Chinese with English abstract).

Söderlund, U.; Patchett, P. J.; Vervoort, J. D.; and Isachsen, C. E. 2004. The ${ }^{176} \mathrm{Lu}$ decay constant determined by Lu-Hf and U-Pb isotope systematics of Precambrian mafic intrusions. Earth Planet. Sci. Lett. 219:311-324.

Song, B.; Zhang, Y. H.; Wan, Y. S.; and Jian, P. 2002. Mount making and SHRIMP dating procedure. Geol. Rev. 48(suppl.):26-30 (in Chinese with English abstract).

Sun, S. S., and McDonough, W. F. 1989. Chemical and isotopic systematics of oceanic basalts: implications for mantle composition and processes. In Saunders, A. D., and Norry, M. J., eds. Magmatism in the ocean basins. Geol. Soc. Lond. Spec. Publ. 42:313-345.

Sun, W. H.; Zhou, M. F.; and Zhao, J. H. 2007. Geochemistry and tectonic significance of basaltic lavas in the Neoproterozoic Yanbian Group (southern Sichuan Province, SW China). Int. Geol. Rev. 49:554-571.

Tatsumi, Y., and Eggins, S. 1995. Subduction zone magmatism. Cambridge, Blackwell, $211 \mathrm{p}$.

Tatsumi, Y.; Hamilton, D. L.; and Nesbitt, R. W. 1986. Chemical characteristics of fluid phase released from subducted lithosphere and origin of arc magmas: evi- 
dence from high-pressure experiments and natural rocks. J. Volcanol. Geotherm. Res. 29:293-309.

Tatsumi, Y., and Nakamura, N. 1986. Composition of aqueous fluid from serpentinite in the subducted lithosphere. Geochem. J. 20:191-196.

Vervoort, J. D., and Blichert-Toft, J. 1999. Evolution of the depleted mantle: Hf isotope evidence from juvenile rocks through time. Geochim. Cosmochim. Acta 63:533-556.

Wallace, P. J. 2005. Volatiles in subduction zone magmas: concentrations and fluxes based on melt inclusion and volatile gas data. J. Volcanol. Geotherm. Res. 140:217240.

Wang, X. L.; Zhou, J. C.; Qiu, J. S.; and Gao, J. F. 2004. Geochemistry of the Meso- to Neoproterozoic basicacid rocks from Hunan Province, South China: implications for the evolution of the western Jiangnan orogen. Precambrian Res. 135:79-103.

White, A. J. R. 1979. Source of granite magmas. Geol. Soc. Am. Abstr. Program 11:539.

White, W. M., and Duncan, R. A. 1996. Geochemistry and geochronology of the Society Islands: new evidence from deep mantle recycling. In Basu, A., and Hart, S. R., eds. Earth processes: reading the isotopic code. Geophys. Monogr. 95. Washington, DC, Am. Geophys. Union, p. 183-206.

Wilson, M. 1989. Igneous petrogenesis. London, Unwin Hyman, $466 \mathrm{p}$.

Woodhead, J.; Eggins, S.; and Gamble, J. 1993. High field strength and transition element systematics in island and back-arc basin basalts: evidence for multi-phase extraction and a depleted mantle wedge. Earth Planet. Sci. Lett. 114:491-504.

Wu, F. Y.; Yang, Y. H.; Xie, L. W.; Yang, J. H.; and Xu, P. 2006. Hf isotopic compositions of the standard zircons and baddeleyites used in U-Pb geochronology. Chem. Geol. 234:105-126.

Xiao, L.; Zhang, H. F; Ni, P. Z; Xiang, H.; and Liu, X. M. 2007. LA-ICP-MS U-Pb zircon geochronology of early Neoproterozoic mafic-intermediate intrusions form NW margin of the Yangtze Block, South China: implications for tectonic evolution. Precambrian Res. 154:221-235.

Yan, D. P.; Zhou, M. F.; Song, H. L.; Wang, X. W.; and Malpas, J. 2003. Origin and tectonic significance of a Mesozoic multi-layer over-thrust within the Yangtze Block (South China). Tectonophysics 361:239-254.

Yan, Q. R.; Hanson, A. D.; Wang, Z. Q.; Druschke, P. A.; Yan, Z.; Wang, T.; Liu, D. Y.; et al. 2004. Late Proterozoic subduction and rifting on the northern margin of the Yangtze Plate, China: implications for Rodinia reconstruction. Int. Geol. Rev. 46:817-832.

Zen, E. 1986. Aluminum enrichment in silicate melts by fractional crystallization: some mineralogic and petrographic constraints. J. Petrol. 27:1095-1117.

- 1988. Phase relations of peraluminous granitic rocks and their petrogenetic implications. Annu. Rev. Earth Planet. Sci. 16:21-52.
Zhang, H. F.; Sun, M.; Lu, F. X.; Zhou, X. H.; Zhou, M. F.; Liu, Y. S.; and Zhang, G. H. 2001. Moderately depleted lithospheric mantle underneath the Yangtze Block: evidence from a garnet lherzolite xenolith in the Dahongshan kimberlite. Geochem. J. 35:315-331.

Zhao, J. H., and Zhou, M. F. 2007a. Geochemistry of Neoproterozoic mafic intrusions in the Panzhihua district (Sichuan Province, SW China): implications for subduction-related metasomatism in the upper mantle. Precambrian Res. 152:27-47.

- 2007b. Neoproterozoic adakitic plutons and arc magmatism along the western margin of the Yangtze Block, South China. J. Geol. 115:675-689.

Zhao, J. H.; Zhou, M. F.; Yan, D. P.; Yang, Y. H.; and Sun, M. 2008. Zircon Lu-Hf isotopic constraints on Neoproterozoic subduction-related crustal growth along the western margin of the Yangtze Block, China. Precambrian Res., doi: 10.1016/j.precamres.2007.11.003.

Zheng, Y. F.; Zhao, Z. F.; Wu, Y. B; Zhang, S. B; Liu, X. M.; and $\mathrm{Wu}$, F. Y. 2006. Zircon U-Pb age, $\mathrm{Hf}$ and $\mathrm{O}$ isotope constraints on protolith origin of ultrahighpressure eclogite and gneiss in the Dabie orogen. Chem. Geol. 231:135-158.

Zhou, D., and Graham, S. A. 1996. The Songpan-Ganzi complex of the West Qinling Shan as a Triassic remnant ocean basin. In Yin, A., and Harrison, T. M., eds. The tectonic evolution of Asia. New York, Cambridge University Press, p. 281-299.

Zhou, M. F.; Kennedy, A. K.; Sun, M.; Malpas, J.; and Lesher, C. M. 2002a. Late Proterozoic arc-related mafic intrusions along the northern margin of South China: implications for the accretion of Rodinia. J. Geol. 110:611-618.

Zhou, M. F.; Ma, Y. X.; Yan, D. P.; Xia, X. P.; Zhao, J. H.; and Sun, M. 2006a. The Yanbian Terrane (southern Sichuan Province, SW China): a Late Proterozoic arc assemblage in the western margin of the Yangtze Block. Precambrian Res. 144:19-38.

Zhou, M. F.; Yan, D. P.; Kennedy, A. K.; Li, Y. Q.; and Ding, J. 2002b. SHRIMP U-Pb zircon geochronological and geochemical evidence for Late Proterozoic arcmagmatism along the western margin of the Yangtze Block, South China. Earth Planet. Sci. Lett. 196:5167.

Zhou, M. F.; Yan, D. P.; Wang, C. L.; Qi, L.; and Kennedy, A. 2006b. Subduction-related origin of the $750 \mathrm{Ma}$ Xuelongbao adakitic complex (Sichuan Province, China): implications for the tectonic setting of the giant Neoproterozoic magmatic event in South China. Earth Planet. Sci. Lett. 248:286-300.

Zhu, W. G.; Liu, B. G.; Deng, H. L.; Zhong, H.; Li, C. Y.; Pi, D. H.; Li, Z. D.; and Qin, Y. 2004. Advances in the study of Neoproterozoic mafic-ultramafic rocks on the western margin of the Yangtze craton. Bull. Mineral. Petrol. Geochem. 23:255-263 (in Chinese with English abstract). 